\title{
Az ELTE 'SzintPlusz' Tématerületi Kiválósági Program első éve: 2019-2020
}

\author{
Kiválósági Program vezető: Perczel András* \\ Eötvös Lóránd Tudományegyetem, Természettudományi Kar, Kémiai Intézet, Szerves Kémia Tanszék, \\ 1117 Budapest, Pázmány Péter sétány $1 / C$
}

Pillérfelelősök: Csámpai Antal, Málnási-Csizmadia András, Mező Gábor

A jelen közleményben ismertetett kutatásokban résztvettek az alább felsorolt munkatársak, s így ők a publikáció társszerzői: Ábrahám Ágnes, Ábrányi-Balogh Péter, Bali Krisztina, Bánóczi Zoltán, Bárány Péter, Beke-Somfai Tamás, Biri-Kovács Beáta, Bodor Andrea, Bősze Szilvia, Csámpai Antal, Dókus Levente, Dürvanger Zsolt, Ecsédi Péter, Enyedi Kata Nóra, Farkas Viktor, Fehér Bence, Flavio Massignan, Goldschmidtné Gőz Viktória, Gyimesi Máté, Gyulai Gergö, Harami Gábor, Harmat Veronika, Hotváth Lilla, Horváti Kata, Jernei Tamás, Keserü György Miklós, Kiss Éva, Kovács Mihály, Lőrincz István, Málnási-Csizmadia András, Mándity István, Mező Gábor, Mihály Judith, Mohammed Bouzbib, Murányi József, Nemes Anikó, Nyitray László, Oláhné-Szabó Rita, Orgován Zoltán, Pálfy István, Pári Edit, Petri László, Rohonczy János, Sinkó Katalin, Sharad Kumar, Shiro Kubuki, Stráner Pál, Szabó Dénes, Szabó Ildikó, Szalai István, Szigyártó Imola Csilla, Szoboszlai Norbert, Tantos Ágnes, Uray Katalin, Vácziné Schlosser Gitta, Varga Imre, Varga Kata, Vellai Tibor, Vida István

A Szint+ kiválósági program közvetlen célja az ELTE TTK szintetikus kapacitásának fejlesztése és bővítése. Közvetett célunk a szintetikus munkákhoz kapcsolódó kollégák, mühelyek és közösségek megerősítése, összehangolása, szinergiájuk növelése azért, hogy hatékonyabbak lehessünk a kutatásban, eredményesebbek a fejlesztésben, és fókuszáltak az innováció területén. Célunk a 1) különböző szintetikus és társult szakterületek megerősítése, összekapcsolása és hálózatba szervezése, 2) a versengő együttmúködés gyakorlatának meghonosítása, 3) a szakterületi szinergia katalízise, valamint és 4) a már sikeres kutatók és műhelyeik együttmüködésének elősegítése és anyagi támogatása. A Kiválósági program keretében öt különböző támogatás formát alakítottunk ki, úgymint 1) tematikus programok, mely keretében azon legkiválóbb projektek támogatása, amelyek keretében 2-3 minősített kutató szinergiában dolgozik együtt egy új és ígéretes szintetikus vagy ahhoz kapcsolódó probléma megoldásán. 2) Gépidő programok amely lehetőséget biztosít arra hogy olyan kutatópárosok kapjanak támogatást, akik dedikált nagymüszereken (röntgen, NMR, ESR, MS, SAXS stb.) kutatnak, és szintetikus munkájuk sikere érdekében mérések elvégzését igénylik. 3) A műszervásárlási program azon kutató párokat támogatja, akik szintetikus eredményességét jelentősen előremozdítja egy-egy 4-6 millió Ft értékű kutatási eszköz beszerzése. Az eszközbeszerzés kapcsán kell megemlítenünk azt hogy 2020-ban egy világszínvonalat megtestesítő ion-mobilizációs tömegspektrométer (IM-MS) került beszerzésre mint egy 200 Millió Ft értékben, valamint már folyik egy magas szinten automatizált $400 \mathrm{MHz}$-es rutin, többcsatornás NMR-készülék, egy rutin Ms-MS és egy aminosav-analizátor beszerzése. 4) A megvalósíthatósági programok olyan szintetikus munkák támogatását végzik, amelyek nagy hazai vagy nemzetközi pályázatok sikeres előkészítését tehetik lehetővé, és amelyek jelentős tudományos, fejlesztői, szabadalmi és/vagy innovációs eredményeket ígérnek. 5) Végül a továbbképzési és oktatásfejlesztési programok - több is van belőlük - az ELTE tudásbázisának bővítését célozza. Különböző szakma-specifikus módszerek megismerését és/ vagy elmélyítését támogatjuk, például „mentor-növendék” program, workshop-ok, tanfolyamok, digitális oktatás, stb.. formájában. Csámpai Antal, Málnási-Csizmadia András és Mező Gábor pillérfelelősök munkáját a SzintPlusz Tématerületi Kiválósági Program vezetője, Perczel András fogja össze. A pillérfelelősök unkáját, valamint az objektív bírálatot odaadó munkájával segíti a Tudományos Tanács aki tagjai abc sorrendben: Ballagi András, Búzás Edit, Gál Péter, Keserü György Miklós, Martinek Tamás, Monostory Katalin, Patthy László, Simig Gyula István és Szüts Dávid, valamint az Innovációs Bizottság: Ballagi András, Dékány Gyula, Magyar Dániel, Pázmány Tamás, Somody Imre és Szente Lajos.

Alább röviden, szinte felsorolás szerüen olvashatók az első évben felkarolt programok célkitűzései, valamint az egyegy mondatba tömörített első eredmények. A tématerületek felsorolása esetleges sorrendben történik, lefedve a szintetikus szerves kémiától, a peptid és fehérje kémián át, a gyógyszer és hatóanyag fejlesztések területeit is érintve, egészen a terápiás fehérjékig minden olyan szakterületet, amely a célkitüzéseinkkel összhangban bővítette és gazdagította az ELTE-TTK és társult kutatóinak szintetikus munkáját.

* Tel.: +36-1- 372-2500/1653; email: perczel.andras@ttk.elte.hu

A projekt résztvevői (lásd a bevezető bekezdést) valamennyien a közlemény társszerzői. 
1. Nanoméretü foldamer oligomerek továbbfejlesztése hidrofób vegyületek egymolekulás transzportjához Farkas Viktor (Dr), Beke-Somfai Tamás (Dr), Bodor Andrea (Dr habil)

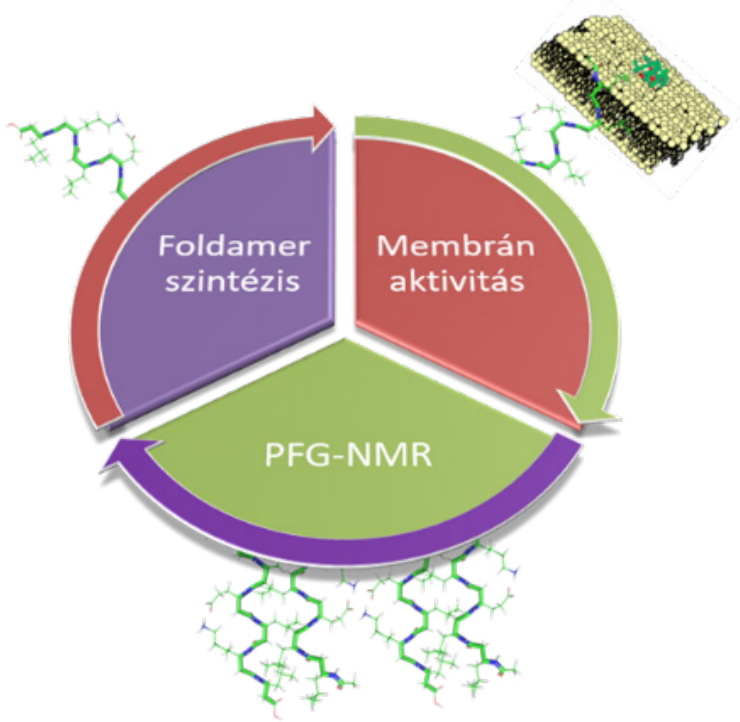

Szintézis/módszer/eljárás: Molekuladinamikai (MD) szimuláció alkalmazása, 8 db peptid asszociációs vizsgálata három, különböző modellel. A kiválasztott $\beta$-peptid szilárdfázisisú peptidszintézise, áramlásos kémiai módszerrel. Szerkezeti vizsgálatok UV, ECD, NMR.

Célkitűzés: Önrendeződő $\beta^{3}$-peptid foldamerekből álló rendszer tervezése és szintézise, mely képes mind vízben, mind lipid kettősrétegben alacsony nanomérettartományú (8-10 nm), 4-10 molekulából álló dinamikus ,bundle” oligomereket képezni.

Eredmény: Az MD számolások eredményeként az egyik $\beta$-peptid megfelelő oligomereket alkot ez alapján kiválasztottuk az első szintetizálandó szekvenciát. Sikeresen előállítottuk a peptidet. Elökísérleteket végeztünk NMR spektroszkópiával hasonló mérettartományban.

2. HER2 receptor specifikus oligopeptidek vizsgálata: receptor-peptid interakciók és térszerkezetek feltárása Biri-Kovács Beáta, Szabó Ildikó (Dr), Stráner Pál (Dr)

HER2-kötő oligopeptidek

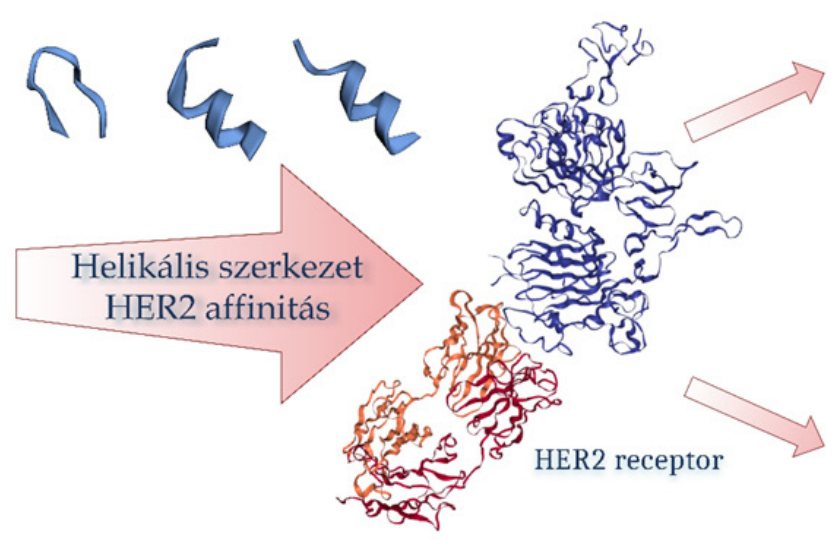

Szintézis/módszer/eljárás: HER2-kötő oligopeptidek és a HER2 receptor előállítása (szilárdfázisú peptidszintézis, heterológ fehérjeexpresszió), a fehérje-peptid interakció vizsgálata (ELISA, SPR), a komplex térszerkezetének meghatározása (NMR, röntgendiffrakció).

Célkitüzés: A fehérje-peptid interakció és a térszerkezet vizsgálatán keresztül olyan HER2 specifikus kötőpeptidek
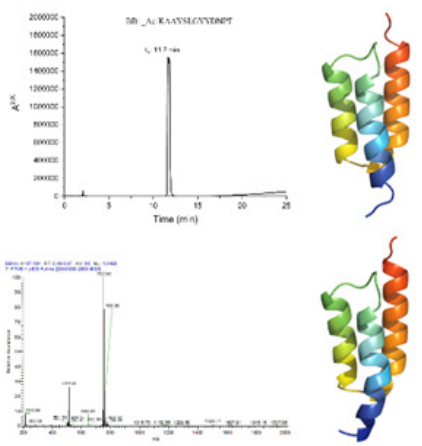

ECD, NMR

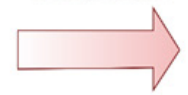

MD-szimulációk

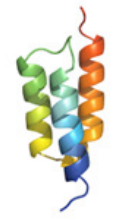

Stabilabb fold
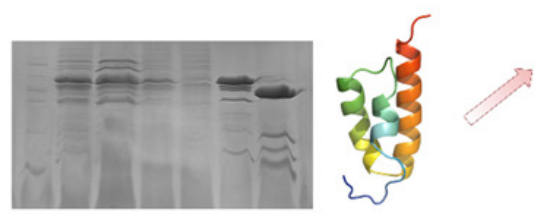

előállítása, melyek a későbbiekben felhasználhatóak HER2 diagnosztikumként és a hatóanyag célbajuttatásának eszközeként is.

Eredmény: HER2-kötő oligopeptideket és módosított Affibody molekulákat állítottunk elő, jellemeztük őket (kémiailag és másodlagos szerkezet alapján), a molekuladinamikai modellek alapján ígéretes HER2 kötődést mutattak. 
3. ß3-Aminosav szubsztituált antimikrobiális peptidek szintézise - Mándity István (Dr), Horváti Kata (Dr)

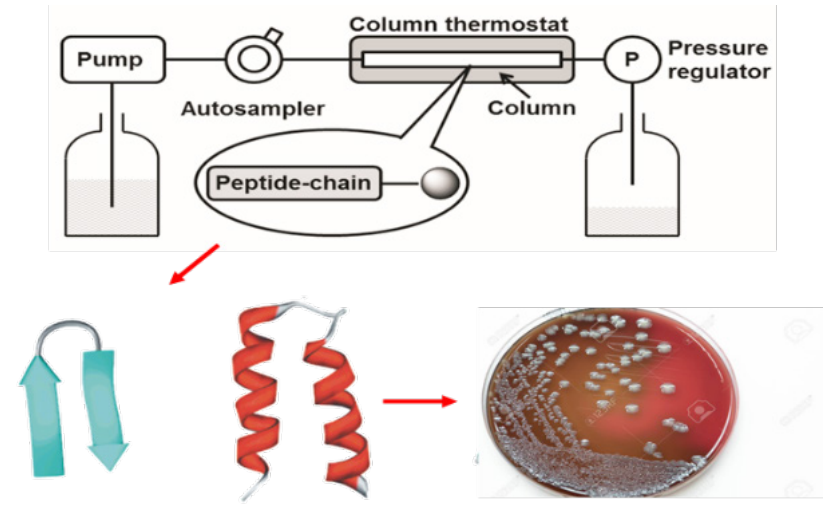

Szintézis/módszer/eljárás: $\beta 3$-aminosav foldamer építő elemeket tartalmazó peptidek szintézise, analízise, valamint a termékek citotoxicitásának és antibakteriális hatásának tesztelése multirezisztens tenyészeteken.

Célkitűzés: Antimikrobiális peptidek szelektivitásának és stabilitásának növelése $\beta^{3}$-aminosavak beépítésével.

Eredmény: Két antimikrobiális peptidbe építettünk be kétféle $\beta^{3}$-aminosavat. Az egyik peptid esetében jelentős változást mértünk: a $\beta^{3}$-aminosav beépítése szignifikánsan csökkentette a peptid citotoxicitását. Így nagymértékben nőtt a vegyület szelektivitása.

4. Peptid-tartalmú polimer nanostruktúrák fejlesztése célsejt specifikus hatóanyag transzport megvalósítására Kiss Éva (Dr), Bősze Szilvia (Dr), Flavio Massignan, Gyulai Gergő

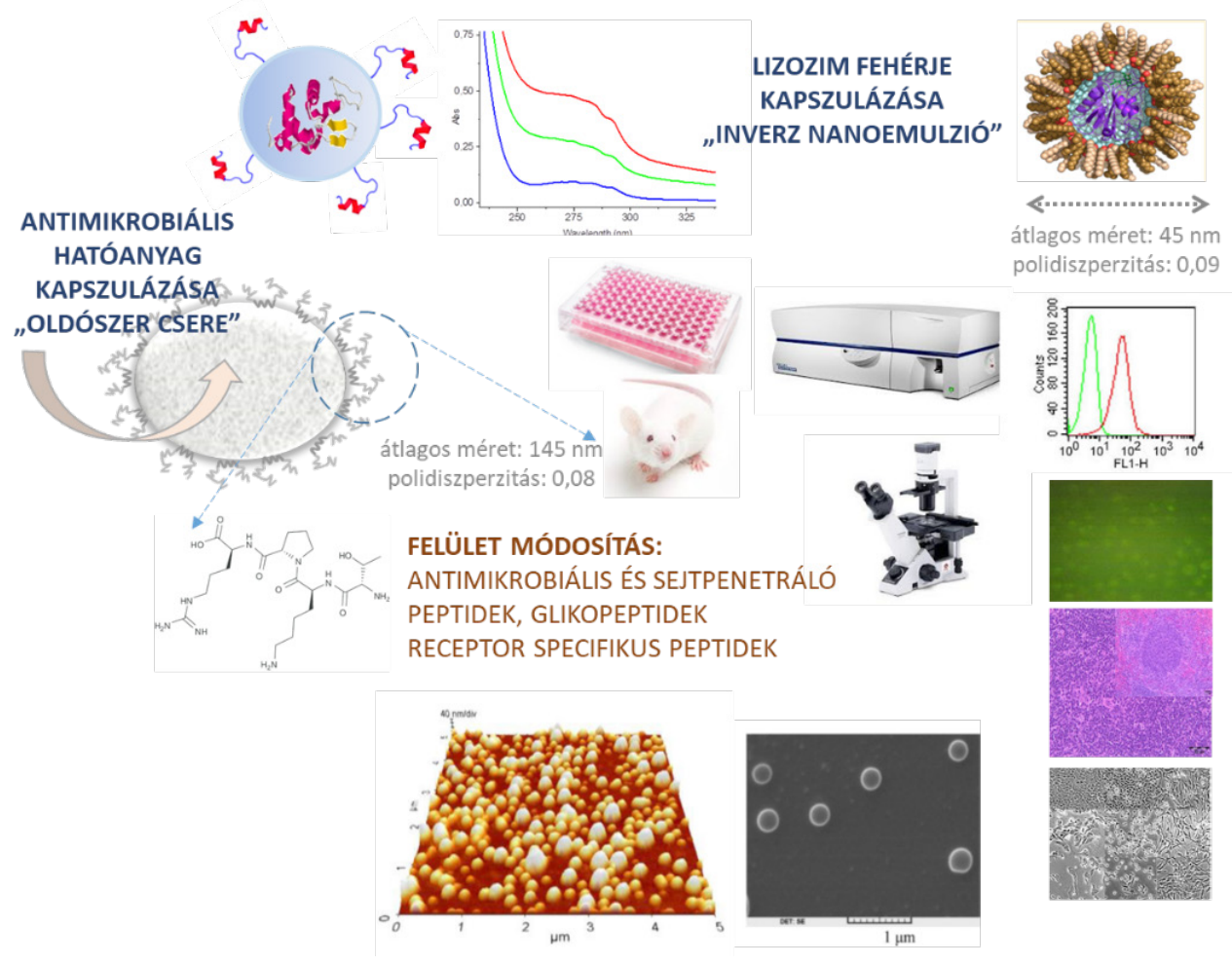

Szintézis/módszer/eljárás: A nanokapszulázható hatóanyagok körét tervezzük kiterjeszteni a gyógyszerkutatásban egyre fontosabbá váló peptid-, fehérje típusú hatóanyagokra. A sejtbejutást és szelektivitást in vitro, az aktivitást in vivo modelleken vizsgáljuk.

Célkitűzés: A biohasznosíthatóság növelésére célsejtjekre specifikus ligandumokkal dekorált polimer alapú nanorészecskéket állítunk elő.
Eredmény: Új gyógyszerhordozókat terveztünk és állítottunk elö. Ezen nanorészecskék in vitro és in vivo rendszerben biztosítják a hatóanyagok programozott felszabadulását a részecske stabilitása és a célsejt specifikus célbajuttatás mellett. 


\section{5. Új hatóanyag - peptid konjugátumok kifejlesztése célzott tumorterápiára} Mező Gábor (Dr), Csámpai Antal (Dr), Bánóczi Zoltán (Dr), Jernei Tamás (Dr), Bárány Péter, Murányi József
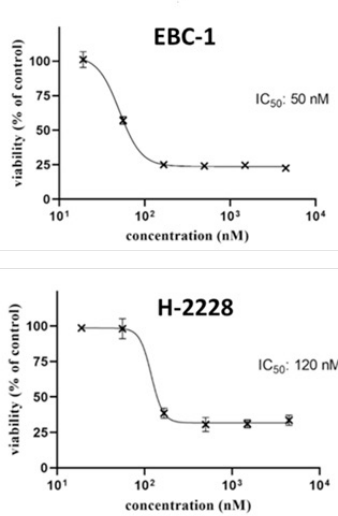

Egy kiemelkedó hatékonyságú prímer amin tüdőrák sejtvonalakon mért IC 50 görbéi.

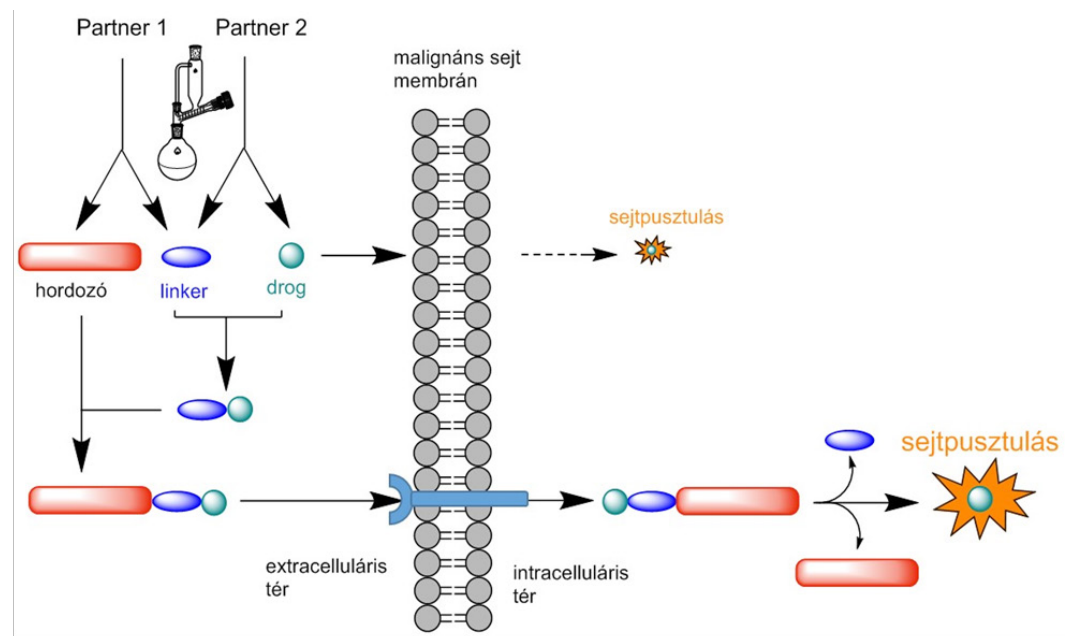

1.) K.J. Fodor, D. Hutai, D., Jernei, T. et al. Molecules 2020, 25, paper 1599. https://doi.org/10.3390/molecules25071599
Szintézis/módszer/eljárás: Racionális tervezés alapján szintetizált kemoterápiás hatóanyag-jelöltekből, kön - nyen kihasadó linkerekből és tumorspecifikus hordozó peptidekből konjugátumok előállítása, antiproliferatív hatásuk és szelektivitásuk vizsgálata.

Célkitűzés: A konjugátumok és a hatóanyag komponensek tesztelésével kapott szerkezet-hatás összefüggéseket fel- használni szándékozzuk fokozott hatással és szelektivitással rendelkező, célzott tumorterápiára alkalmas új termékek fejlesztéséhez.

Eredmény: Előállítottunk új kalkonokat, valamint heterociklusos aminokat. A szekunder aminokat publikáltuk ${ }^{1}$, a prímer aminokat oltalmi eljárás alá vonjuk. Előállítottuk és tanulmányoztuk Daunomicin-konjugátumok potenciális aminosav metabolitjait.

6. Ortogonálisan védett nem természetes aminosavak szintézise peptidek aggregációjának gátlására és turn-szerkezetek módosítására - Nemes Anikó (Dr), Enyedi Kata Nóra (Dr)
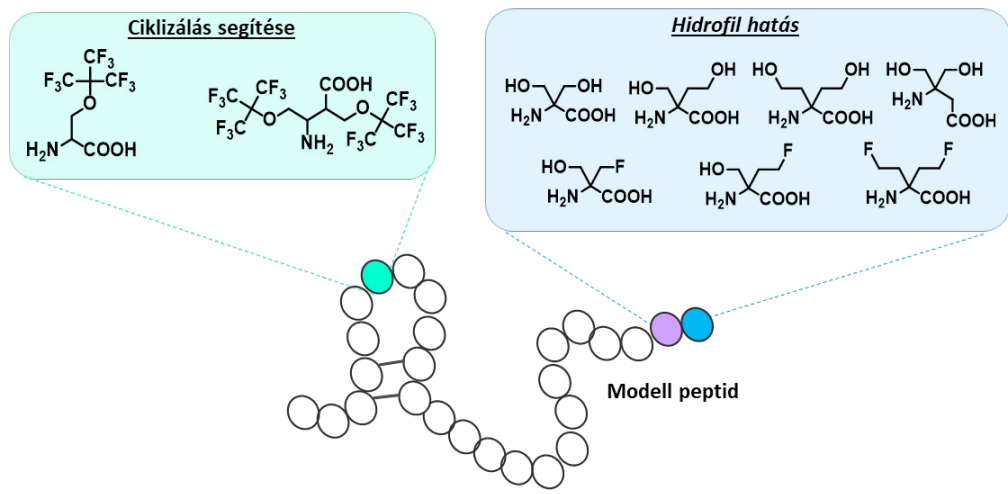

Szintézis / módszer / eljárás: Kutatásunk alapja az $\alpha$-hid-

mészetes aminosavak beépítésével. Ezért célunk egy olyan roximetil-szerin, melynek oldallánchosszabbított, fluortartalmú és $\beta$-aminosav, ill. nonafluor-tercier-butil-csoporttal módosított analógjait állítjuk elő. Hatásukat vizsgáljuk peptid-aggregáció és térszerkezet szempontjából.

Célkitüzés: Biológiailag aktív peptidek több problémát jelentő tulajdonsága (pl. aggregáció) kompenzálható nem terpeptidszintetikus vegyület-tárnak a kialakítása amely, több területre is megoldást nyújt.

Eredmény: Előállítottuk a hidroximetil-szerint és néhány védett származékát (O-Bn, NH-Boc), illetve az O-perfluorterc-butilszerint. Modell peptideket szintetizáltunk aggregációs vizsgálatokhoz és ciklikus peptidek vizsgálatához. 
7. Új irányító peptiddel dekorált liposzómák kialakítása hatóanyag célba juttatásra

Mező Gánor (Dr), Szoboszlai Norbert (Dr), Dókus Levente

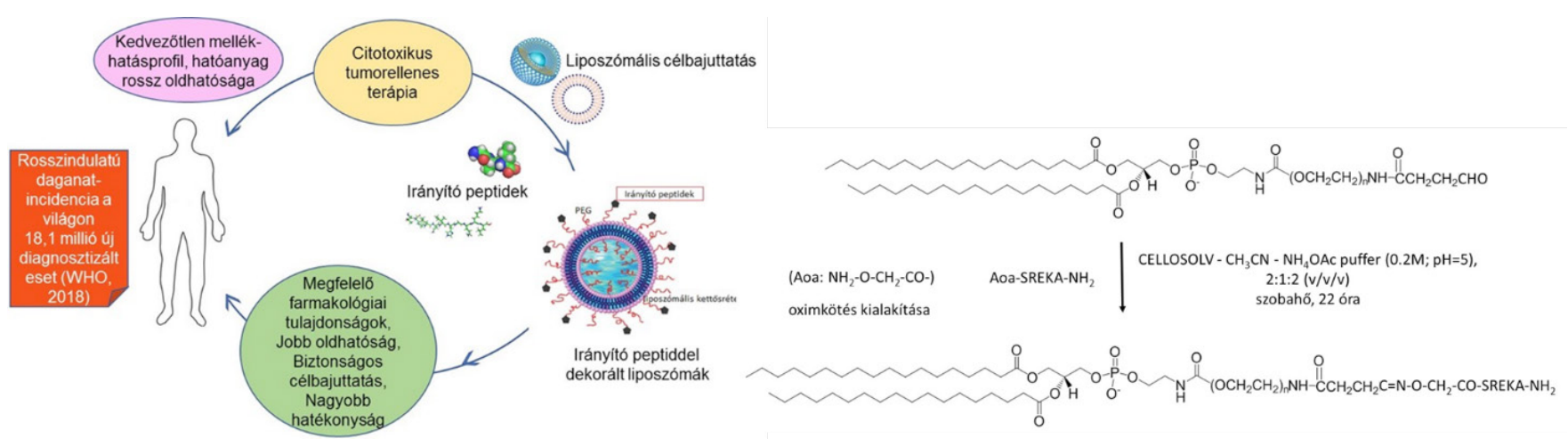

Szintézis/módszer/eljárás: Funkcionalizált (aldehid, tiol, maleimid, azid) DSPE-PEG molekulákhoz kapcsoltunk SREKA vagy CREKA irányító peptidet kemoszelektív ligációs módszerrel oxim-, tioéter-, triazolkötésen keresztül.

Célkitüzés: Irányító molekulával dekorált liposzómák előállítása hatóanyagok célzott tumorsejtbe juttatására.
Eredmény: A konjugálási reakciók körülményeit optimalizáltuk és megfelelő tisztítási és analitikai körülményeket dolgoztunk ki. Összehasonlítottuk az egyes esetekben kapott kiterme-léseket. Ezek alapján eddig az oximkötést tartalmazó konjugá-tum előállítása tűnik a leghatékonyabbnak. Elkezdődtek a célzó molekulával dekorált hatóanyagot tartal-mazó liposzómák előállítása és összehasonlító vizsgálatuk in vitro és in vivo körülmények között.
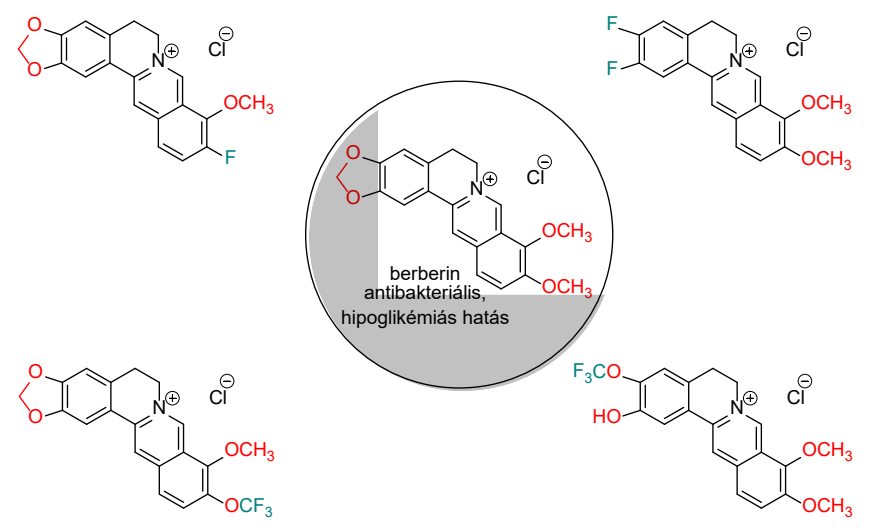

Szintézis/módszer/eljárás: A természetben előforduló alkaloidok hasznos vezérmolekulák lehetnek a gyógyszerfejlesztések során. Ezért munkánk első részében izokinolinvázas alkaloidok fluortartalmú funkciós csoportokkal (F, CF3, CH2CF3) helyettesített változatait tervezzük elöállítani.

Célkitüzés: Ismeretes, hogy a $\mathrm{C}-\mathrm{H}$ vagy $\mathrm{C}=\mathrm{O}$ kötés $\mathrm{C}-\mathrm{F}$ kötéssé történő helyettesítése kedvezően hat a biológiailag

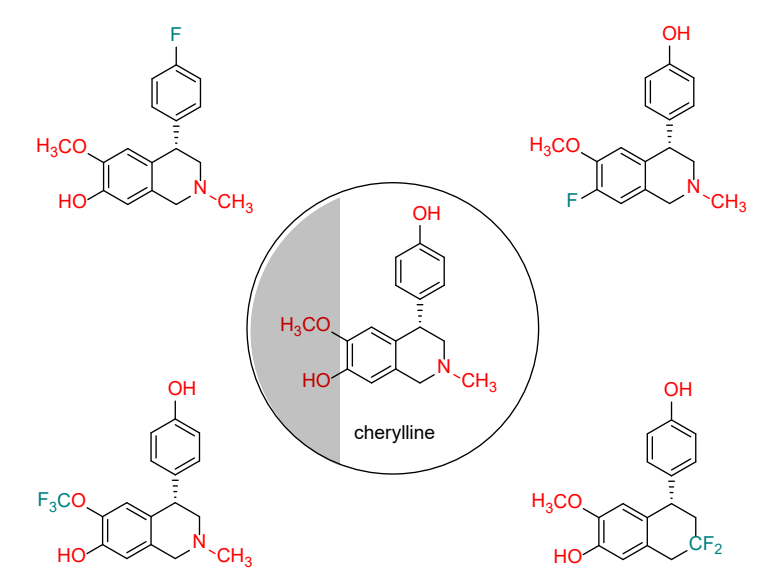

aktív molekulák tulajdonságaira. Ezért tervezzük a természetben előforduló, biológiai aktivitással rendelkező vegyületek fluortartalmú változatainak előállítását.

Eredmény: Megvalósítottuk 4 norbelladin analóg szintézisét. Ezek gyürüzárással berberin származékokká alakíthatók. Előállítottunk poliszubsztituált benzolszármazékokat, amelyek a lobarinsav utolsó intermedierjei. 
9. Szintézis áramlásos rendszerekben - Szalai István (Dr), Varga Imre (Dr)
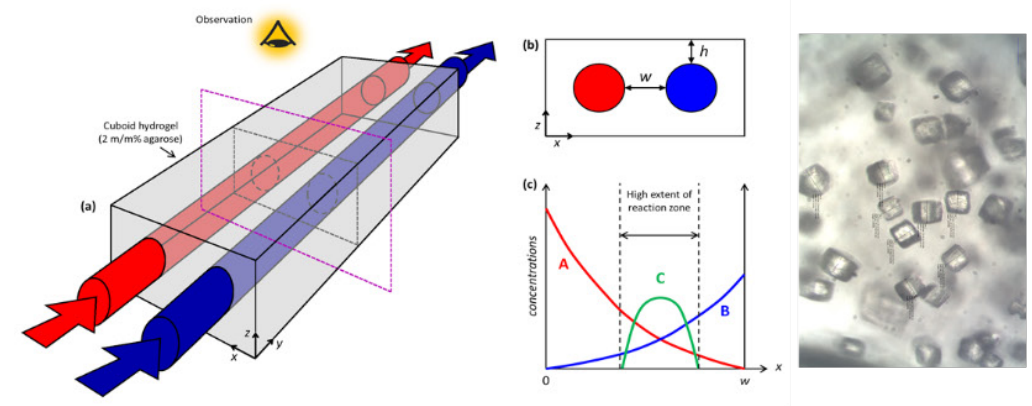

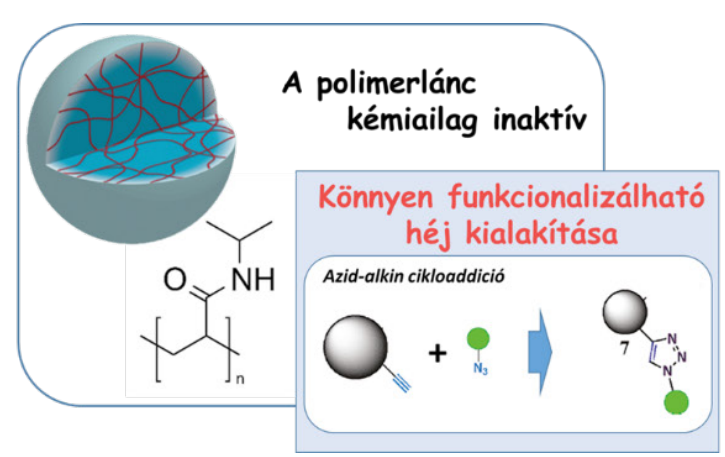

Szintézis/módszer/eljárás: Szeparált csatornákat tartalmazó lágy hidrogélek reaktorként való alkalmazhatóságának tesztelése. Katalitikus komplexek és nanorészecskék immobilazására alkalmas, funkcionalizálható csoportokkal rendelkező lágy nanostruktúrák szintézise.
Célkitüzés: Az új áramlásos technika tesztelése és katalizátor hordozó lágy nanostruktúrák elöállítására alkalmas szintézismódszer kidolgozása.

Eredmény: Megtörtént egyszerủ szervetlen kémiai reakciók segítségével. Azid-alkin cikloaddiciós reakcióval történő funkcionalizálásra alkalmas mag/héj szerkezetű pNIPAm mikrogél részecskék szintézise megtörtént.

10. In-cell NMR módszer fejlesztése sejtbejutó hatású HSV-1 gD peptidekkel konjugált izotópjelölt K-Ras fehérjével Uray Katalin (Dr), Bősze Szilvia (Dr), Vida István, Pálfy Gyula (Dr)

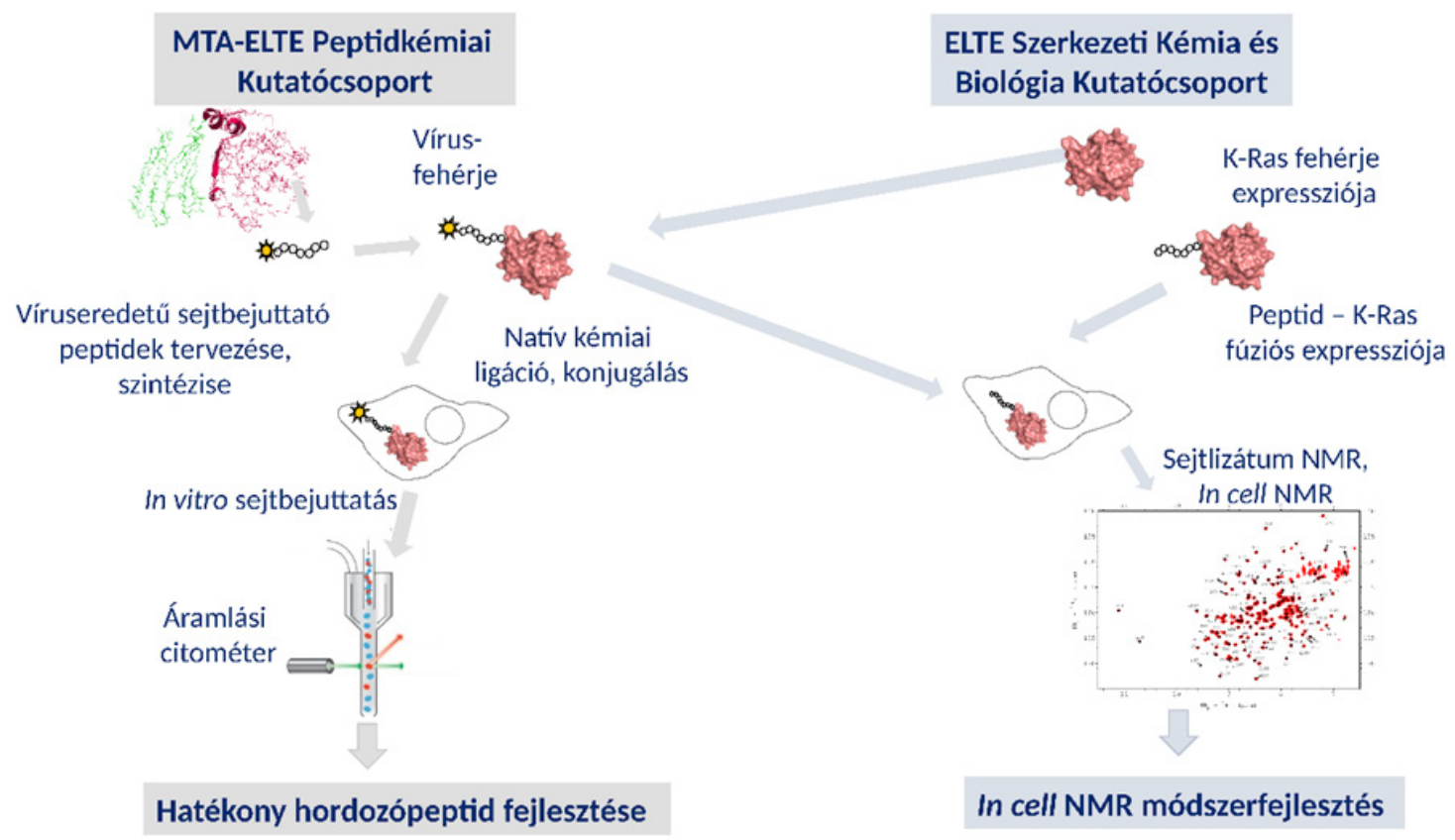

Szintézis/módszer/eljárás: Bakteriális expresszióval elöállított, izotópjelölt K-Ras fehérjét konjugálunk vírus eredetű peptidhez, és a konstrukció sejtbejutását citométerrel, a térszerkezetét humán sejtlizátumban és sejten belül NMR spektroszkópiával vizsgáljuk.

Célkitüzés: Fehérjék sejtbe juttatására alkalmas vírus eredetű peptidhordozó fejlesztése. Ezen megközelítéssel in- cell NMR módszer fejlesztése, és tesztelése a K-Ras fehérje sejten belüli szerkezetének vizsgálatán keresztül.

Eredmény: Izotópjelölt K-Ras előállítása, mutagenezisek a KRas-(Cys light)-Cys előállításához, mCherry-Cys expressziója és konjugálása vírus eredetü peptiddel, a sejtbejutás bizonyítása. ${ }^{1} \mathrm{H}-\mathrm{NMR}$ és ${ }^{1} \mathrm{H},{ }^{15} \mathrm{~N}-\mathrm{HSQC}$ mérések intakt sejtekkel és sejtlizátumokkal. Lizátumokban sikeres spetrum felvétel ${ }^{15} \mathrm{~N}-\mathrm{K}-$ Ras fehérje egyik mutánsáról. 
11. Fluoreszcens lipid nano-kapszulák előállítása fehérje/arany komplexek felhasználásával Varga Imre (Dr), Mihály Judith (Dr), Fehér Bence
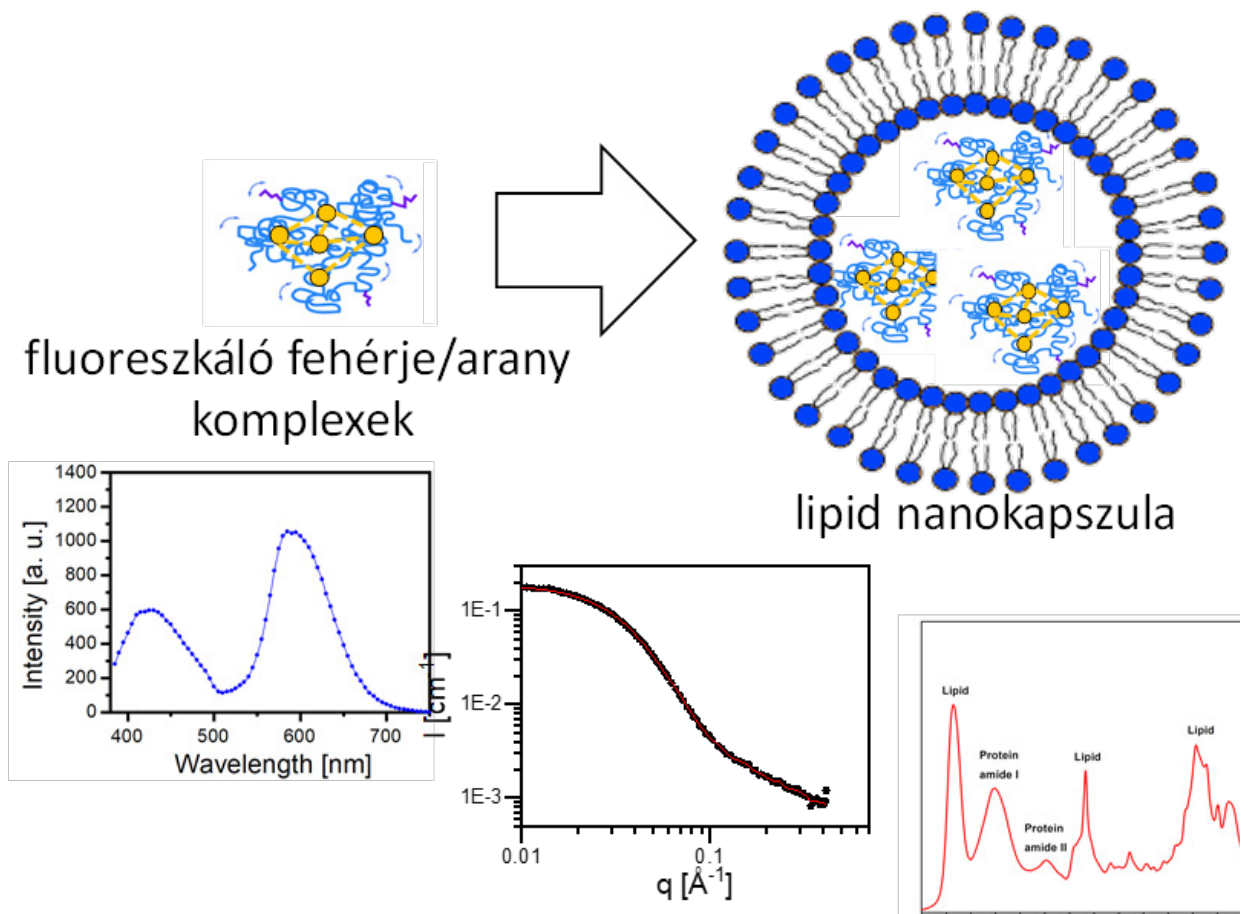

Szintézis/módszer/eljárás: Fluoreszcens fehérje/arany komplexeket tartalmazó lipid nanokapszulák előállítása és jellemzése biofizikai (IR spektroszkópia, kisszögü röntgenszórás) és optikai módszerekkel.

Célkitüzés: A fluoreszcens fehérje/arany komplexeket lipid nano-kapszulákba csomagolva védjük meg a fluoreszcencia

megszűnését eredményező környezeti hatásoktól, megnövelve biológiai alkalmazásuk lehetőségét.

Eredmény: $\mathrm{Ca}^{2+}$-ionok jelenléte növeli a fehérje/arany komplex bezárási hatásfokát. Összehangolt IR spektroszkópiai és SAXS mérésekkel követni tudtuk a fehérje szerkezeti változásait azAu@BSA komplexben.

12. Humán Piwi fehérjék szerkezeti és funkcionális jellemzése - Vellai Tibor (Dr), málnási-Csizmadia András (Dr)

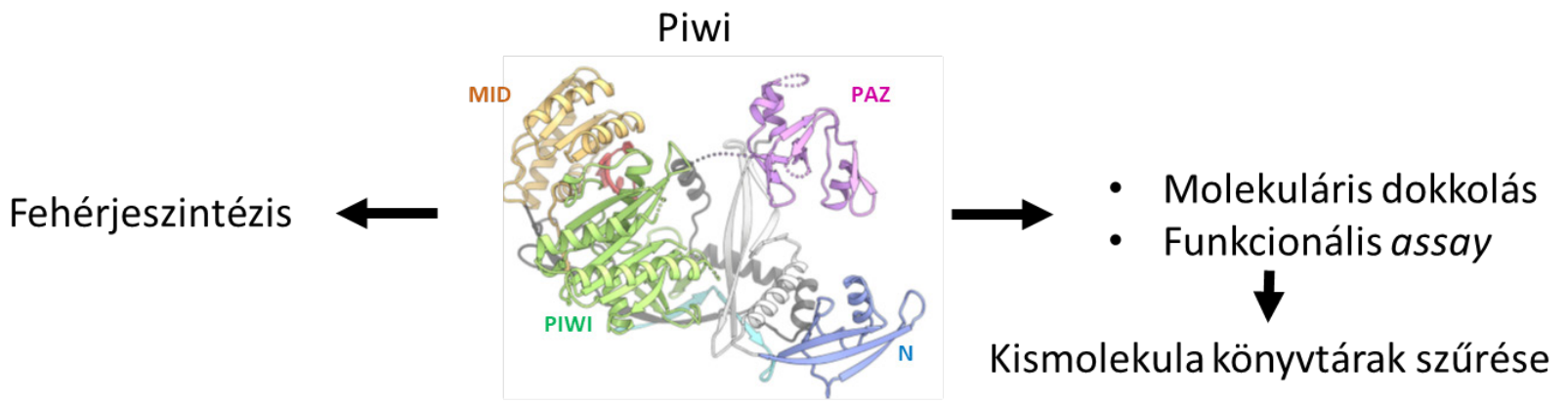

Szintézis/módszer/eljárás: A biokémiai csoport által előállított humán Piwi fehérjéket a genetikai csoport funkcionális tesztek kidolgozásához használja fel. Végső cél: Piwi gátló kismolekulák (gyógyszerjelöltek) azonosítása.

Célkitűzés: A genom stabilitás fenntartásában alapvető szerepet játszó Piwi fehérjék (emberben: PIWIL1-4) szerke- zetének függvényében potens Piwi gátló, anti-tumor hatású kismolekulákat kívánunk azonosítani.

Eredmény: A Piwi domén 3D szerkezetének ismeretében molekuláris dokkolással potenciális kötőpartnereket azonosítottunk, a fehérjék előállítása folyamatban van, egy in vivo Piwi tesztrendszert fejlesztettünk. 


\section{Vanadátrétegek elektromos tulajdonságait befolyásoló szerkezeti paraméterek} Sinkó Katalin (Dr), Rohonczy János (Dr), Mohammed Bouzbib, Shiro Kubuki (Dr)

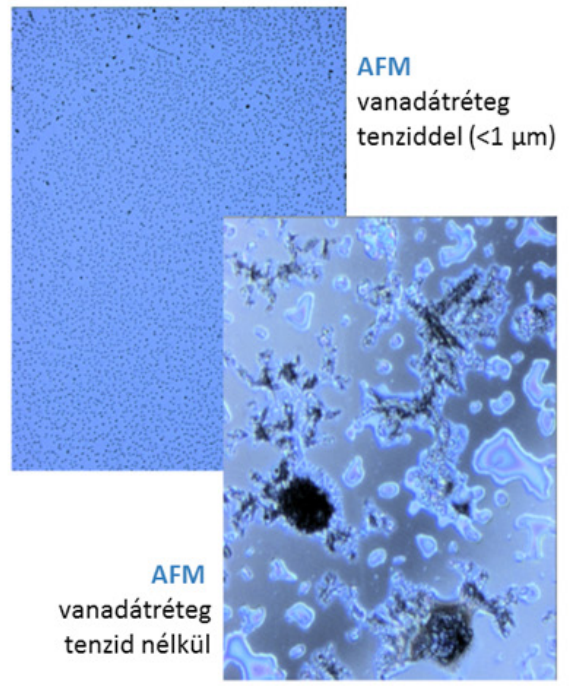

51V NMR szimulálása

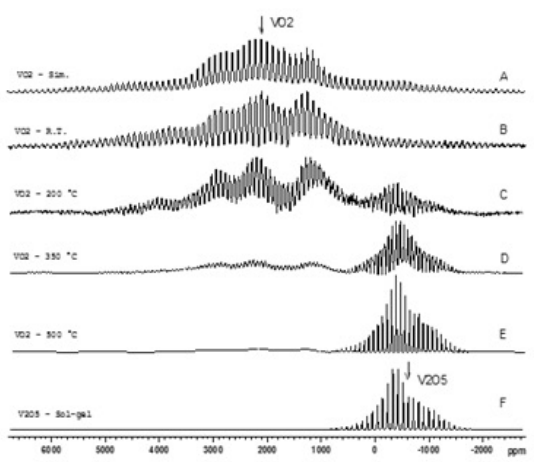

(A) szimulált $\mathrm{VO}_{2}$ spektrum, (B) szobahômérsékletű $\mathrm{VO}_{2}$, (C) $200{ }^{\circ} \mathrm{C}$-on hökezelet $\mathrm{VO}_{2}$, (D) $350^{\circ} \mathrm{C}$-on hökezelet $\mathrm{VO}_{2}$

(E) $500{ }^{\circ} \mathrm{C}$-on hőkezelet $\mathrm{VO}_{2}$, (F) $\mathrm{V}_{2} \mathrm{O}_{5}$ sol-gel módszerrel elöállítva

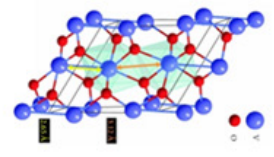

$\alpha-\mathrm{VO}_{2}$

Knight-shift

$\mathrm{VO}_{2}$ simulation data

$\delta$ (iso) $\quad 2102 \mathrm{ppm}$

$\delta(\mathrm{CSA}) \quad 1356 \mathrm{ppm}$

$\eta(C S A) \quad 0.8$

CQ(Quad) $4.71 \mathrm{MHz}$

П(Quad) $\quad 0.50$

Euler $\alpha \quad 165^{\circ}$

Euler $\beta \quad 5^{\circ}$

Euler $y \quad 36^{\circ}$

B $\quad 4850 \mathrm{~Hz}$

MASR $\quad 14 \mathrm{kHz}$

50
Szintézis: Szol-gél szintézis során pH 2 kolloid oldat készül NH4VO3 vizes oldatából különböző savak (salétrom-, ecet-, citromsav) vagy kationcserélő alkalmazásával. A keletkező H3VO4 már képes kondenzálódni. Szobahőmérséklet, 70 - és $400{ }^{\circ} \mathrm{C}$-os kezelések után a rendszer alkalmas réteghúzásra. Összehasonlításul $800{ }^{\circ} \mathrm{C}$-on olvasztott és vízben diszpergáltatott V2O5 szolgált.

Célkitüzés: Cél egy költséghatékony, variálható rétegvastagságú, jó elektromos tulajdonságokkal rendelkező vana- dátréteg kialakítása. Fontos feladat a szerkezeti paraméterek hatásának feltérképezése is az elektromos tulajdonságokra.

Eredmény: Az eddigi kísérletek alapján a legjobb szintézisnek az ioncserélőt és tenzidet alkalmazó út bizonyult. A szintézissel homogén vékony réteget lehet előállítani. Szilárd ${ }^{51} \mathrm{~V}$ MAS NMR mérésekkel és szimulációval jellemezni tudjuk a $\mathrm{V}^{4+}$ és $\mathrm{V}^{5+}$ állapotokat és környezetüket.

\section{Az aminosav tartalmú peptidek; szintetikus megoldások és biológiai aktivitás} Bánóczi Zoltán (Dr), Szabó Ildikó (Dr)
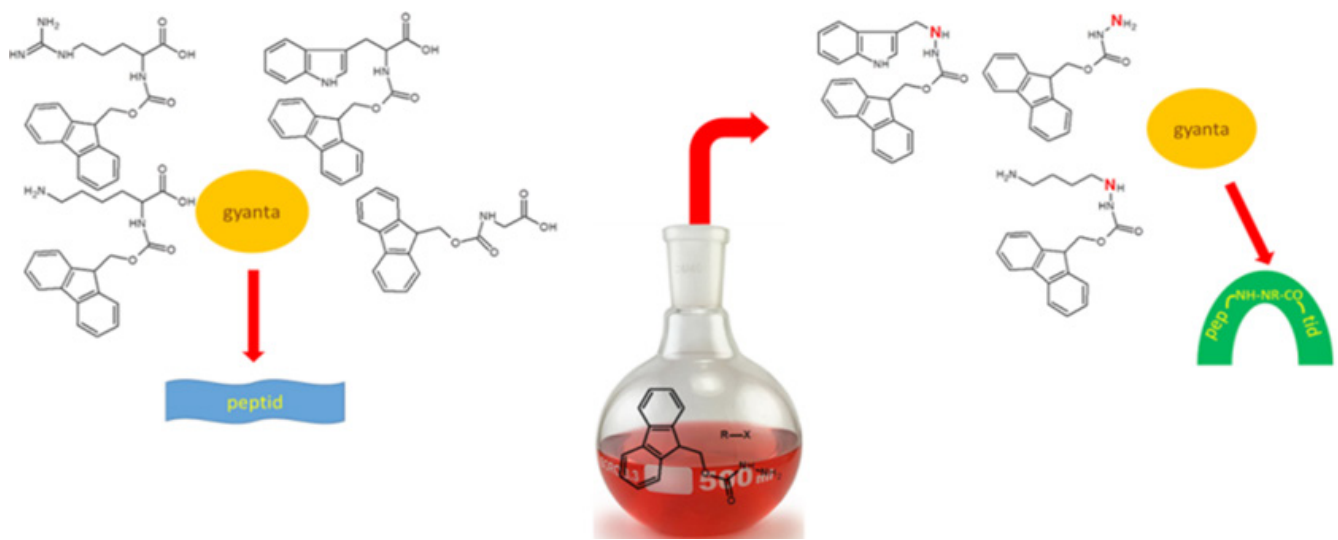

Szintézis/módszer/eljárás: Aza-glicin, -lizin, -arginin és -triptofán tartalmú aza-peptidek szilárdfázisú szintézise hidrazin származékok felhasználásával. A hidrazin-származékok előállítását reduktív alkilezéssel valósítjuk meg.

Célkitüzés: Aza-aminosav szubsztitúciók hatásának vizsgálata ismert biológiai aktivitással rendelkező peptidek stabilitására, szerkezetére, valamint biológiai aktivitásukra (sejtbejutás, citosztatikus hatás).

Eredmény: Sikeresen előállítottuk és kémiailag jellemeztük az aza-lizin és -triprofán aminosav-származékok szintéziséhez szükséges hidrazin-származékokat, valamint a kontroll peptideket és konjugátumaikat. 
15. Humán egyszálú DNS-kötő fehérjék szintézise a fázisszeparáció sajátságainak vizsgálatához Harami Gábor (Dr), Kovács Mihály (Dr)

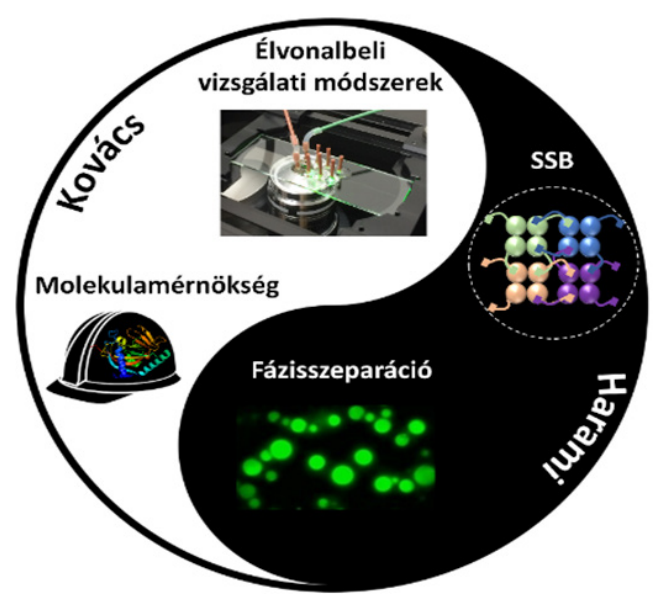

Szintézis/módszer/eljárás: Szintetikusan előállított emberi hSSB1-2 fehérjék fázisszeparációs sajátságait derítjük fel in vitro és in vivo élvonalbeli fluoreszcencia-mikroszkópia és biofizikai mérések ötvözésével.

Célkitüzés: Célunk, hogy a DNS-hibajavítás új mechanizmusit tárjuk fel és lépést tegyünk a fázisszeparáció jelensége alkalmazott felhasználásának irányába a humán SSB1-2 fehérjék vizsgálatán keresztül.

Eredmény: Sikeresen előállítottuk a humán SSB1-2 fehérjéket és elsőként mutattuk ki, hogy a hSSB2 DNS-függő módon képes a fázisszeparációra míg a hSSB1 foszforilálatlan formában nem fázisszeparál.

16. Az első nem-izom miozin-2 (NM2) specifikus inhibítor kifejlesztése Sharad Kumar (Dr), Gyimesi Máté (Dr), Lőrincz István (Dr)

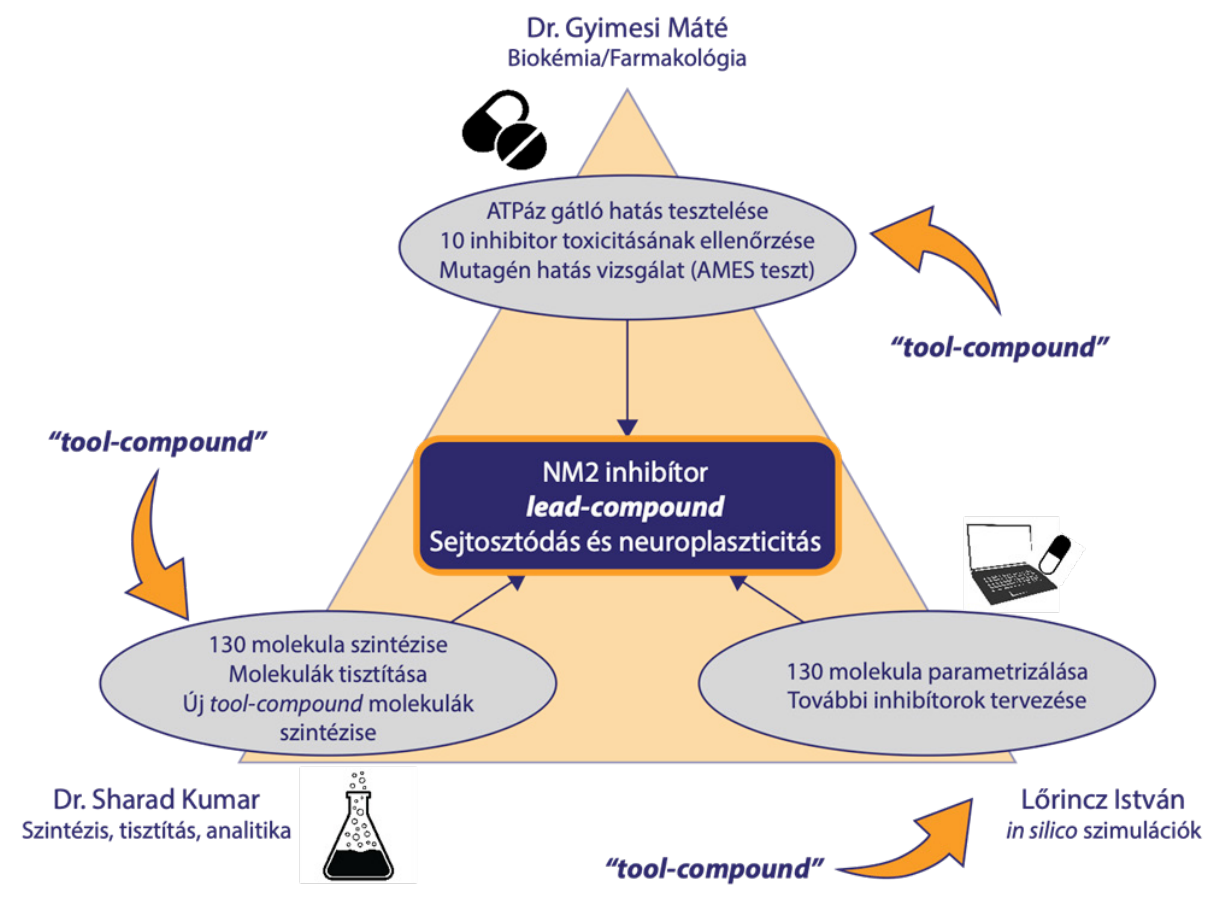

Szintézis/módszer/eljárás: „tool-compound” származékok in silico tervezése, ,tool-compound” naftátszármazékok, kombinatórikus kémiai elöállítása, tisztított molekulák ATPáz gátlásának tesztelése 7 miozin-2 izofomán, továbbfejlesztés „lead” molekulává.

Célkitűzés: NM2 specifikus „lead molekula” előállítása, mely rendkívüli jelentőséggel bírna 1) kemoterápiás szerek,
2) sejtregenrációra, 3) idegsejt nyúlványnövesztésére ható gyógyszerek kifejlesztésében.

Eredmény: 130+ naftát származék parametrizálása és molekuladinamikai szimulációja, 100+ molekula szintézise, analitikája, ATPáz tesztek elindítása NM2 izoformákon, AMES mutagenitás teszt 1 molekulán, Neurit növekedési tesztek optimalizálása 5 molekulával. 
17. DrugRas: onkogén K-Ras mutánsokra ható vegyületek tervezése, szintézise, szűrése és jellemzése Perczel András (Dr, egy.tan.), Pálfy Gyula (Dr), Vida István, Keserü György Miklós (Dr), Ábrányi-Balogh Péter (Dr), Orgován Zoltán, Petri László

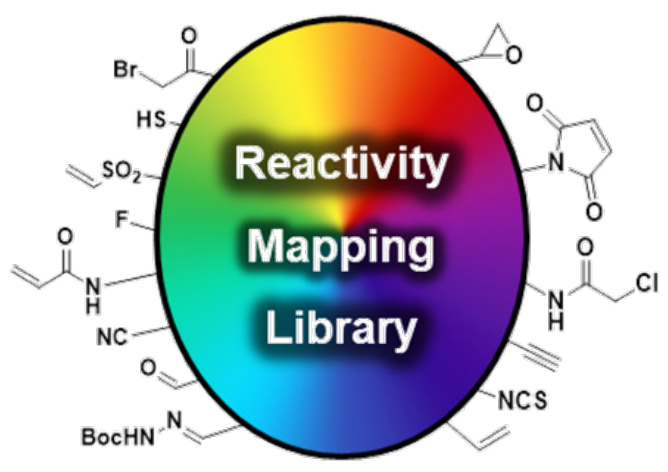

Szintézis/módszer/eljárás: Egy speciális kovalens fragmenskönyvtár szürése NMR módszerekkel. A kovalens kötés validálása a ligandum oldaláról ${ }^{19} \mathrm{~F}-\mathrm{NMR}$ módszerrel, valamint a fehérje oldaláról ${ }^{1} \mathrm{H},{ }^{15} \mathrm{~N}-\mathrm{HSQC}$ módszerrel a kötődés helyzetének meghatározásával együtt.

Célkitűzés: K-Ras-G12C onkogén mutáns kovalens módosítására alkalmas kötőelemek azonosítása, majd ezek felszerelése ismert K-Ras-G12C inhibitor és általunk talált alapvázra, az új alapvázak további optimálása.
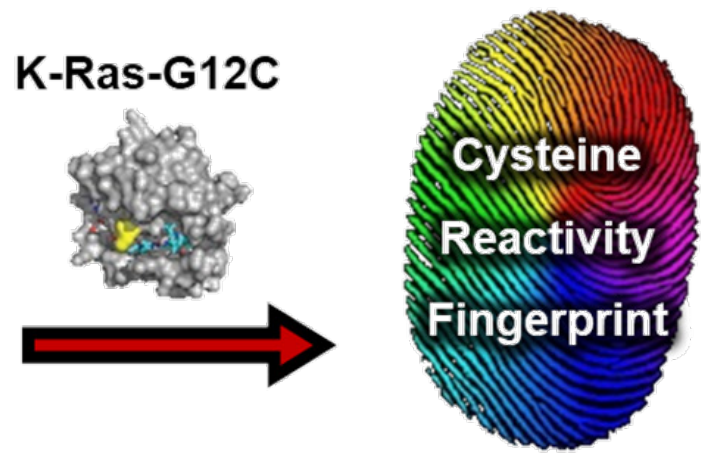

Eredmény: 28 vizsgált kötőelemből 15-öt találtunk a K-Ras-G12C-GDP kovalens módosítására alkalmasnak. Figyelemre méltó, hogy a ligandum oldaláról ${ }^{19} \mathrm{~F}-\mathrm{NMR}$ méréssel azonosított kötődéseket a fehérje oldaláról ${ }^{1} \mathrm{H},{ }^{15} \mathrm{~N}$ HSQC mérésekkel is meg tudtuk erősíteni. Utóbbi módszerrel további 7 jelölt molekulából 6 esetében mutattunk ki kötődést.

18. Gépidő felhasználás NMR 700 MHz készüléken - Bodor Andrea (Dr. habil), Tants Ágnes (Dr), Beke-Somfai Tamás (Dr)

Célkitűzések: a) Az RNS-kötő, 106 aminosav hosszú EZH2 rendezetlen loop jellemzése fiziológiás körülmények között, a foszforiláció hatásának vizsgálata. b) A hisztatin származék DHVAR, 14 aminosav hosszú, amfipatikus, pozitív töltésủ antimikrobiális hatású peptid és a tartrazin ételfesték kölcsönhatásának leírása.

Eredmény: A hisztatin származék DHVAR4 peptid és tartrazin (TZ) ételfesték kölcsönhatásának vizsgálata ter- mészetes izotópeloszlás mellett 2D homo- és heteronukleáris; illetve transzlációs diffúziós mérésekkel $1 \mathrm{mM}$ koncentráció: a 14 aminosav hosszúságú peptid rendezetlen Elektrosztatikus kölcsönhatás a pozitív töltésü peptid és a negatív töltésü TZ között. D(DHVAR4) $=2,1 \mathrm{e}-10 \mathrm{~m}^{2} / \mathrm{s}$; $\mathrm{D}(\mathrm{TZ})=4,6 \mathrm{e}-10 \mathrm{~m}^{2} / \mathrm{s}$. Az RNS-kötö, 106 aminosav hosszú EZH2 loop fiziológiás körülmények között mind 278K, mind 298K hőmérsékleten rendezetlen. Teljes aszignáció 3D mérések segítségével. 
19. Ciklodextrin hordozók és ciklodextrin - hatóanyag komplexek szerkezetének meghatározása NMR spektroszkópiai módszerrel: a molekuláris konstrukciók összehasonlító jellemzése Bősze Szilvia (Dr), Horváti Kata (Dr), Goldschmidtné Gőz Viktória (Dr), Csámpai Antal (Dr)

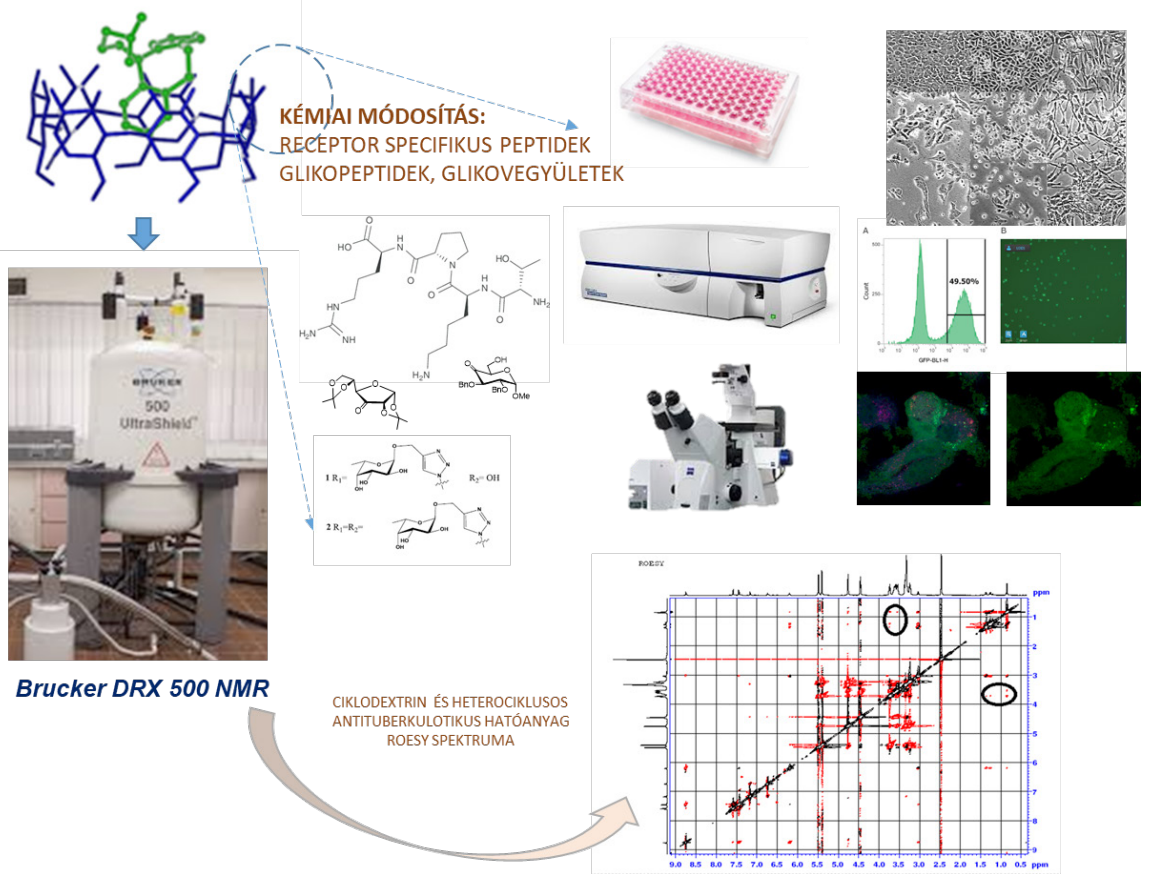

Szintézis/módszer/eljárás: Ciklodextrin alapú zárvány komplexeket állítunk elő. Meghatározzuk ezen komplexek szerkezetét, valamint a komplexképzés molekuláris feltételeit. Vizsgáljuk ezen komplexek sejtbejutását.

Célkitűzés: Módosított ciklodextrin vázak előállítása hatóanyagok célbajuttatására és biodisztribúciójuk vizsgálatára.
Eredmény: A komplexek létrejöttét nagyfelbontású ${ }^{1} \mathrm{H}$ - és ${ }^{13} \mathrm{C}-\mathrm{NMR}$ (optimalizált NOESY, ROESY) módszerekkel, a kémiai eltolódás változások és intermolekuláris kölcsönhatások detektálásán keresztül igazoltuk. Bizonyítottuk, hogy a ciklodextrinek egyes hatóanyagok célbajuttatására és biodisztribúciójuk vizsgála-tára megfelelő jelöltek lehetnek.

20. Új kristályosító chaperonok hatékonyságának vizsgálata: Fehérjekrisztallográfiai vizsgálatok az ELTE-CrystalLAB nagymüszereinek használatával - Nyitray László (Dr), Ecsédi Péter, Varga Kata, Harmat Veronika (Dr),

Dürvanger Zsolt, Stráner Pál (Dr)

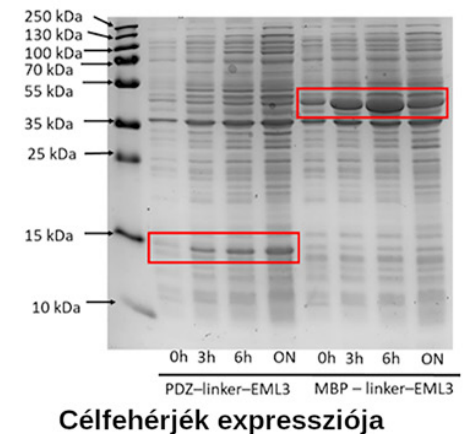

Célfehérjék expressziója

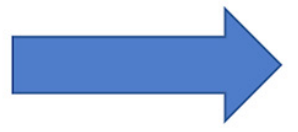

Kristályosítás, szerkezetmegoldás

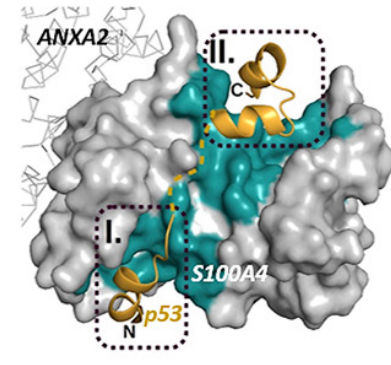

Szerkezetek elemzése
Módszer: Célfehérje - kristályosító chaperon rendszerek tervezése, a fehérjék expressziója, kristályositása, majd a szerkezet megoldása röntgendiffrakcióval és a kristálybeli kölcsönhatások elemzése.

Célkitűzés: Új típusú kristályosító chaperon rendszerek tervezése az annexin A2 és a dinein könnyü lánc 1 fehérjék felhasználásával. Az új kristályosító chaperonok hatékonyságának vizsgálata.

Eredmény: Sikeresen alkalmaztuk chaperonként az annexin A2 fehérjét, mely az elterjedten használt MBP-nél hatékonyabbnak bizonyult. A dinein könnyü lánc 1 és a célfehérjék expressziója folyamatban van. 


\section{Müszervásárlás keretében beszerzésre került 2 db Jasco UV-4075 kétcsatornás detektor beszerzése} Farkas Viktor (Dr), Horváti Kata (Dr)

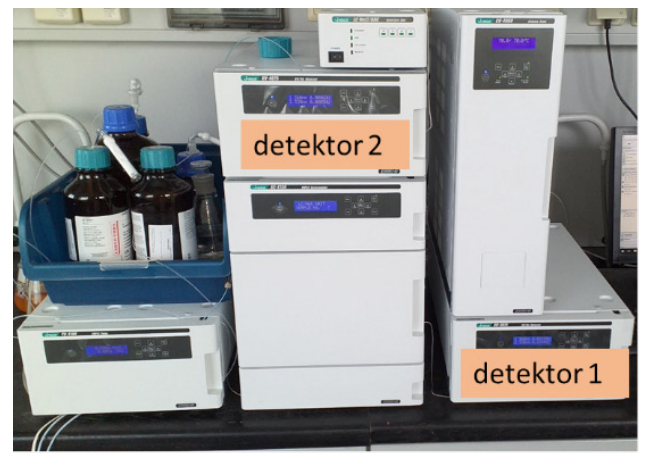

Kereskedelmi forgalomban megvásárolható, HPLC modulokból összerakott áramlásos peptidkémiai készülék segítségével gyorsan, kis költséggel, minimális környezetkárosító hatás mellett tudunk tiszta nyersterméket (akár 95\%) eredményező peptidet, kimérát és foldamert szintetizálni. A pályázott műszerek (2db UV detektor) segítségével mo-

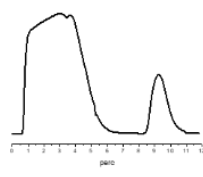

det1 kapcsolási

reakció

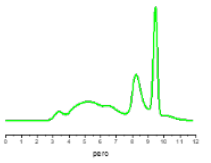

det2 nitorozni tudjuk az aminosavak kapcsolási reakcióit és a védőcsoportok hasítását. A pontos detektálás hozzásegít minket ahhoz, hogy megtalálhassuk az optimális kapcsolási és hasítási reakciókörülményeket és pontosabb képet kaphatunk a peptidszintézis közben lezajlódó reakciók mechanizmusáról és kinetikájáról.

22. Mikrofluidikai reaktor - Ábrahám Ágnes (Dr), Gyulai Gergő (Dr)
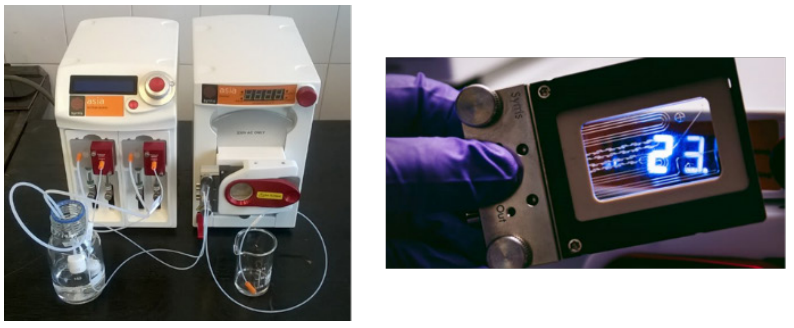

A Határfelületi- és Nanoszerkezetek Laboratóriumában munkánk egyik fó fókusza polimer alapú, gyógyszerhordozó nanorészecske rendszerek előállítása és vizsgálata. A mikrofluidikai technikák segítségével a kis mennyiségben rendelkezésre álló peptid alapú hatóanyagok nagy hatékonyságú nanoformulázása is megvalósítható. A SzintPlusz Müszervásárlási pályázat keretében beszerzésre került ASIA Mikrofluidikai rendszer jelentős kapacitás bővítést jelent a nanoformulázott készítmények előállításához. Csoportunk az MTA-ELTE Peptidkémiai Kutatócsoport

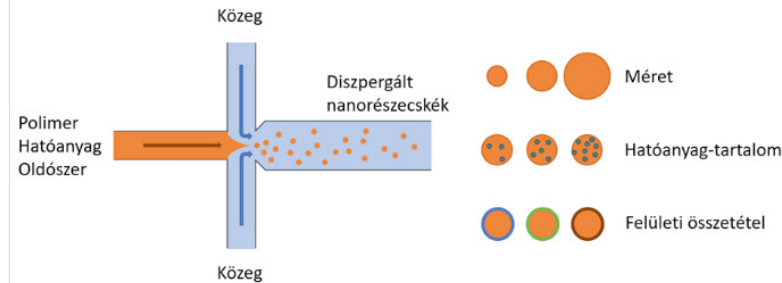

munkatársaival együttműködve különböző kismolekulás, illetve peptid alapú hatóanyagok és hatóanyagjelöltek nagy hatékonyságú kapszulázását fogja megvalósítani. A müszer segítségével a kis mennyiségben rendelkezésre álló anyagokkal is vizsgálni tudjuk a kapszulázási hőmérséklet és áramlási sebesség hatását a részecske méretre, a hatóanyag tartalomra és a kapszulázási hatékonyságra, ezáltal optimalizálhatjuk a becsomagolt anyagok biohasznosulását. Az eszköz beszerzése megvalósult, a kísérleti munka rövidesen megkezdődhet. 
23. 2 új LC20 egység beszerzése - Horváti Kata (Dr), Farkas Viktor (Dr)

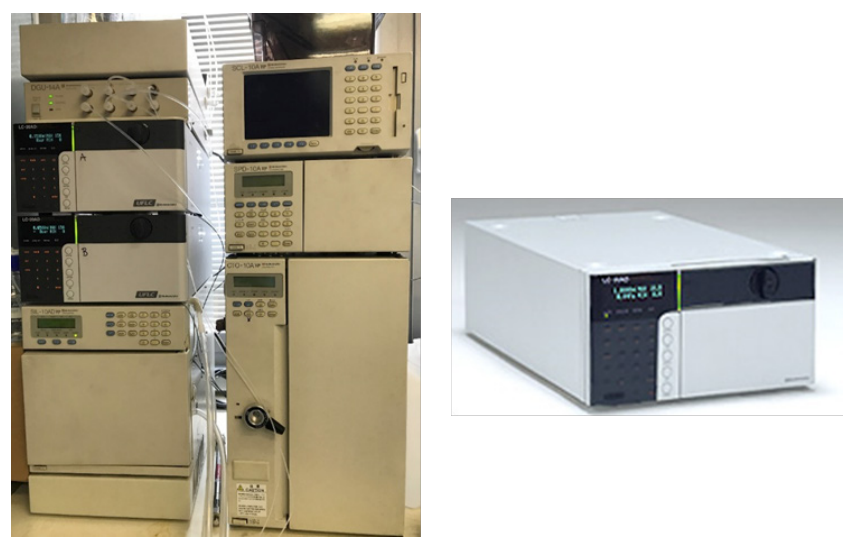

Peptidek terápiás alkalmazása a modern gyógyszerfejlesztés egyik legígéretesebb területe. Több, mint 60 engedélyeztetett peptid-alapú hatóanyag van jelenleg forgalomban és további 150 peptid szerepel jelenleg aktív klinikai fázisban [1]. A farmakokinetikai tulajdonságok javítására és specificitás növelésére számos szintetikus stratégia került kidolgozásra az elmúlt években (pl. nem-természetes aminosavak beépítése, peptid-gerinc módosítása, konjugálás, formulázás, stb.). Az MTA-ELTE Peptidkémiai Kutatócsoportban (PKCs) és az MTA-ELTE Fehérjemodellező Kutatócsoportban (FMKCs) régóta folynak kutatások a peptidkémia területén. A szerkezetvizsgálat (CD, NMR) és a biológiai tesztek (antibakteriális tesztek, citotoxicitás vizsgálat, stb.) elvégzése előtt a felhasznált peptideket minden esetben tisztítani szükséges HPLC rendszer segítségével, illetve az elöállított peptidek homogenitásának ellenőrzése is HPLC segítségével történik. A müszervásárlási pályázat lehetőséget adott számunkra, hogy fejlesszük a HPLC rendszert és kibővítsük laborjaink tisztítási és analitikai kapacitását. Ennek eredményeként nagyobb mennyiségben tudunk elvégezni teszteket az elöállított biológiailag aktív peptidekkel.

\section{Internalizálódott hatónyagok mennyiségi meghatározása és sejten belüli megoszlásának, lokalizációjának} vizsgálata - Oláhné Szabó Rita (Dr), Bősze Szilvia (Dr), Horváth Lilla, Vácziné Schlosser Gitta (Dr)

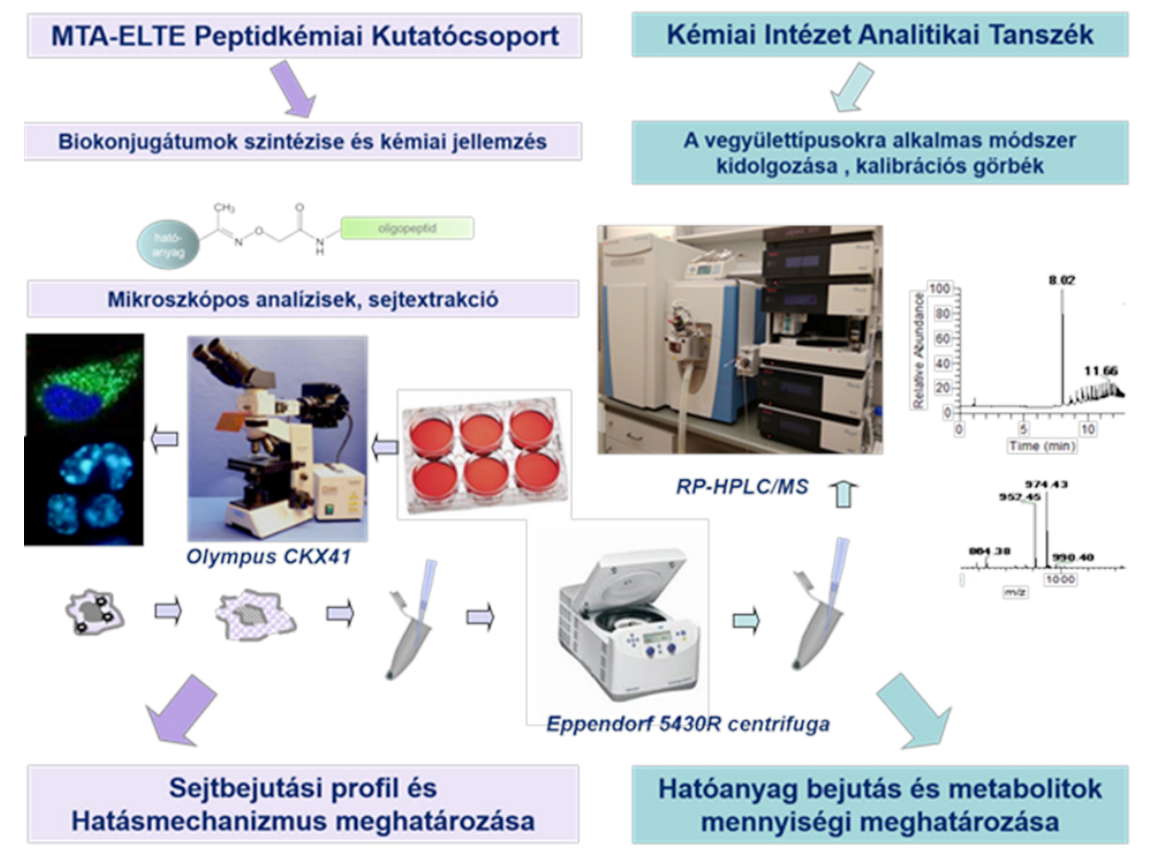

A hatóanyagok szerkezet-hatás összefüggéseinek feltárása során fontos a vegyületek sejtbejutásának, disztribúciójának jellemzése. RP-HPLC-MS módszer alkalmazásával vizsgáltuk hatóanyag jelöltekkel történő kezelést követően a sejtekbe jutott anyagmennyiséget kvantitatív/szemikvantitatív módon, sejtextraktumokból. Az extraktumok RPHPLC-MS elemzésre történő előkészítése az extrahálási folyamat során több centrifugálási- és tisztítási lépéssel történik az Eppendorf 5430R centrifuga alkalmazásával. Az RP-HPLC-MS meghatározásokat megelőzően, az extrakció előtt, fluoreszcens mikroszkóppal vizsgáltuk a hatóanyagok sejtbejutását és intracelluláris lokalizációját. A fluoreszcens mikroszkóphoz tartozó képalkotó munkaállomás alkalmazása lehetővé tette, hogy fluoreszcens sajátságú hatóanyagjelöltek, nano- és peptidhordozó konstrukciók sejtbejutási sajátságait összevessük az extraktumokból nyert mennyiségi adatokkal. A sejten belüli disztribúciót képalkotással és mennyiségi elemzéssel is követhettük, fontos szerkezet - hatás összefüggések definiálása mellett. 
25. A Mentor-Növendék program keretében támogatást nyert a 'Szalicilanilid-származékok autofágia indukciójának vizsgálata glioma sejteken: Western blot módszer betanítása és optimalizálása' címú program

Biri-Kovács Beáta és Horváth Lilla

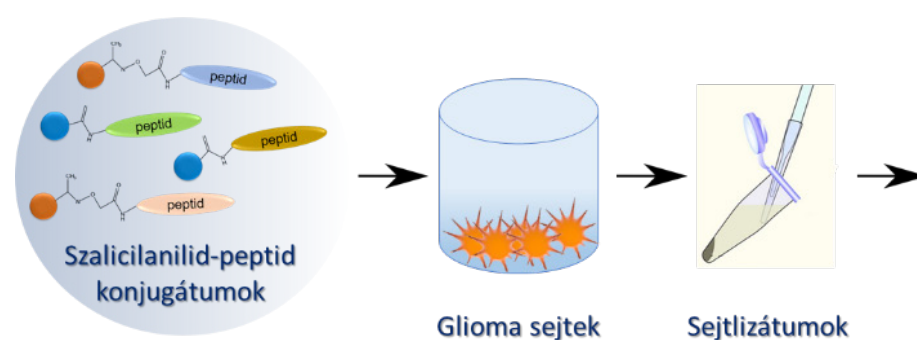

Glioma sejtek

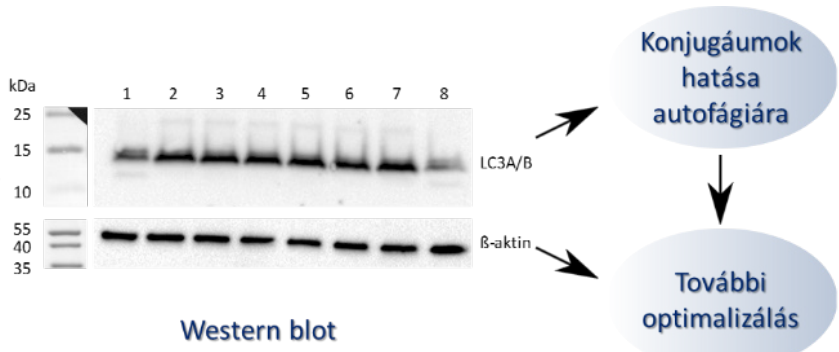

tumok autofágiára kifejtett hatásának vizsgálata és összehasonlítása Western blot módszer alkalmazásával, glioma sejtvonalon.

Eredmény: Western blot módszer beállítása szalicilanilid származékokkal. A vegyületek autofágiára kifejtett hatása összemérhető a klinikumban alkalmazott kontrollal, és jelentősen eltér a kezeletlen kontrolltól.

26. Valamint a 'Peptidszintézis - vírus eredetü sejtbejuttató peptidek szintézise és membrán-kölcsönhatásának vizsgálata’ címü kooperáció - Uray Katalin (Dr), Szigyártó Imola Csilla (Dr)

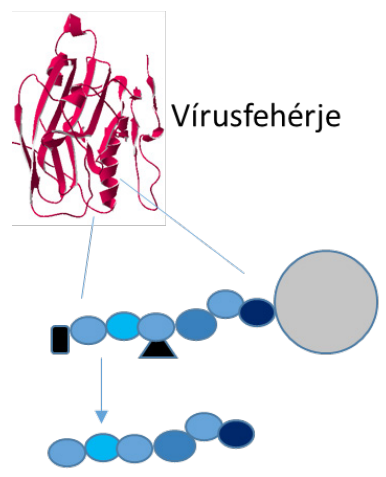

Szilárdfázisú peptidszintézis

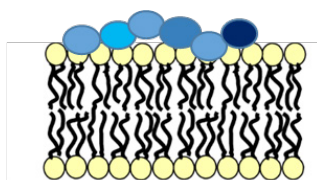

Membrán-kölcsönhatás vizsgálat

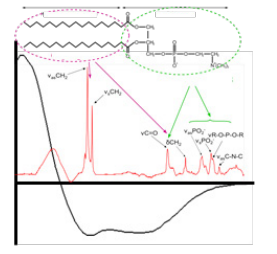

Térszerkezetvizsgálat: ECD, LD, IR spektroszkópia
Peptidszintézis - vírus eredetű sejtbejuttató peptidek szintézise és membrán-kölcsönhatásának vizsgálata.

Eredmény: HSV eredetű peptideket állítottunk elő. A tisztított, azonosított peptidek szerkezetét modell membránok jelenlétében és anélkül infravörös és polarizált fényspektroszkópiai mérésekkel vizsgáltuk. 
27. Továbbá a 'Polietilén-iminnel (PEI) stabilizált arany nanorészecskék felületerôsített Raman spektroszkópiai (SERS) tesztelése' - Mihály Judith (Dr) és Bali Krisztina
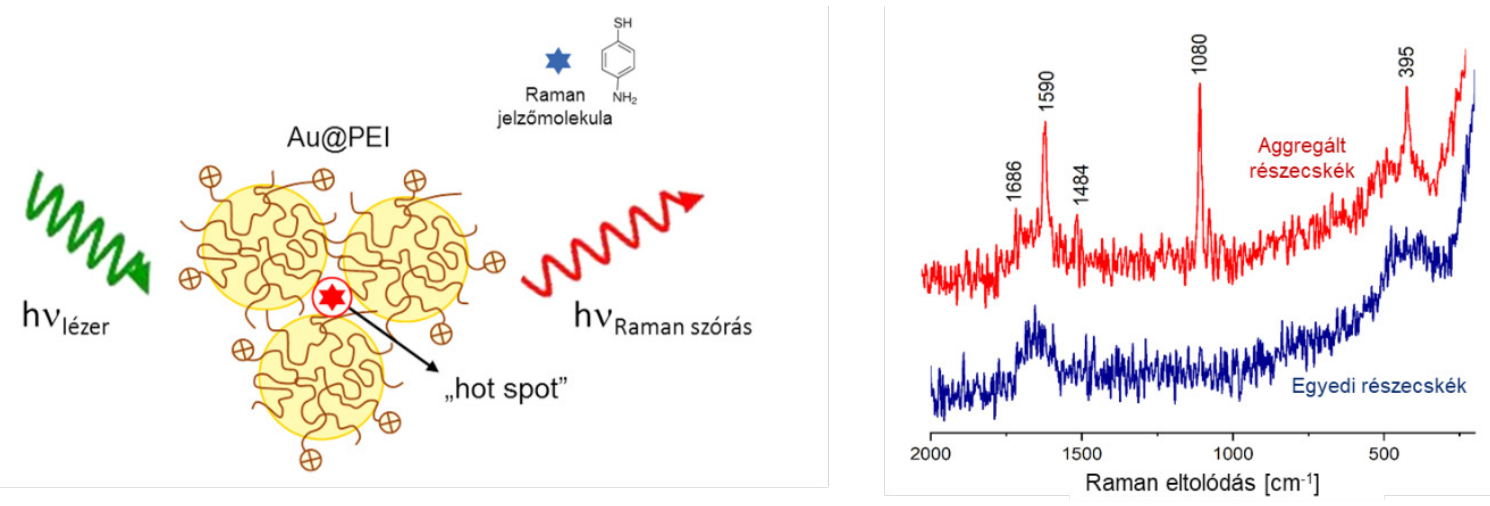

Módszerek: Szilárdfázisú peptidszintézissel állítunk elő víruseredetủ peptideket. A peptidek kölcsönhatását membránmodellekkel cirkuláris és lineáris dikroizmus, valamint infravörös spektroszkópiával tanulmányozzuk.

Célkitűzés: A felületerősített Raman spektroszkópia gyakorlati alapjainak átadása. A szerzett tapasztalatokat bio-

lógiai minták vizsgálatára alkalmas SERS szubsztrátumok kialakítására szeretnénk felhasználni.

Eredmény: A különböző felületi tulajdonságokkal rendelkezőAu@PEI nanorészecskék eltérő SERS tulajdonságokat mutattak. A SERS sávok detektálásához minden esetben a nanorészecskék spontán vagy indukált aggregációjára volt szükség.

SzintPlusz munkadélutánok keretében, minden hónap 3. csütörtökén (14.00-16.00 óra között) amíg lehetett, addig személyesen, azóta pedig a virtuális térben, Temas-en tartottunk érdekes rövid előadások keretében előadói üléseket. Legyen Ön is szakmai munkacsoportunk tagja, a kiváló élménynek részese, vagy jöjjön el és halgassa meg a legfrissebb tudományos eredményeket, mert a Szint+ 2021 és 2022-ben is folytatódik!

\section{Köszönetnyilvánítás}

Dr. Borhy László (rektor), Dr. Scheuer Gyula (kancellár), Dr. Darázs Lénárd (rektorhelyettes), Dr. Szalay Péter egyetemi tanár, dr. Rikker Emília (főigazgató), valamint az ELTE pályázati központ és a Természettudományi Kar adminisztratív munkatársainak.

\section{Hivatkozások}

1. Aronson, M. R.; Medina, S. H.; Mitchell, M. J. Peptide functionalized liposomes for receptor targeted cancer therapy. APL Bioeng. 2021, 5, 011501. https://doi.org/10.1063/5.0029860

2. Zhang, Y.; Wei, J.; Liu, S.; Wang, J.; Han, X.; Qin, H.; Lang, J.; Cheng, K.; Li, Y.; Qi, Y.; Anderson, G. J.; Sukumar, S.; $\mathrm{Li}, \mathrm{S}$.; Nie, G. Inhibition of platelet function using liposomal nanoparticles blocks tumor metastasis. 2017, 7, 1062-1071. https://doi.org/10.7150/thno.17908
3. Gyimesi, M.; Horváth, A.I.; Túrós, D.; Suthar, S.K.; Pénzes, M.; Kurdi, C.; Canon, L.; Kikuti, C.; Ruppel, K.M.; Trivedi, D.V.; Spudich, j.A.; Lőrincz, I.; Rauscher, A.Á.; Kovács, M.; Pál, E.; Komoly, S.; Houdusse, A.; Málnási-Csizmadia, A. Cell. 2020 Oct 15;183(2):335-346.e13. https://doi.org/10.1016/j.cell.2020.08.050

4. Pénzes, M.; Túrós, D.; Máthé, D.; Szigeti, K.; Hegedűs, N.; 2, Rauscher, A.Á.; Tót, P.; Ivic, I.; Padmanabhan, P.; Pál, G.; Dobolyi, Á., Gyimesi, M.; Málnási-Csizmadia, A. Theranostics. 2020 Apr 6;10(12):5341-5356. https://doi.org/10.7150/thno.42077

5. Rauscher, A.Á.; Gyimesi, M.; Kovács, M.; MálnásiCsizmadia, A. Trends Biochem Sci. 2018 Sep;43(9):700-713. https://doi.org/10.1016/j.tibs.2018.06.006

6. Dudás, E.F.; Bodor, A. Quantitative, Diffusion NMR Based Analytical Tool To Distinguish Folded, Disordered, and Denatured Biomolecules. Anal.Chem. 2019, 91,8,4929-4933. https://doi.org/10.1021/acs.analchem.8b05617

7. Ashkenasy, G., et al. Systems chemistry. Chemical Society Reviews 46.9 (2017): 2543-2554. https://pubs.rsc.org/en/content/articlelanding/2017/CS/ C7CS00117G

8. van Rossum, S. AP, et al. Dissipative out-of-equilibrium assembly of man-made supramolecular materials. Chemical Society Reviews 46.18 (2017): 5519-5535.

https://pubs.rsc.org/en/content/articlelanding/2017/CS/ C7CS00246G

9. Dúzs, B., and Szalai I. A simple hydrogel device with flow-through channels to maintain dissipative non-equilibrium phenomena. Communications Chemistry 3.1 (2020):16. https://www.nature.com/articles/s42004-020-00420-y

10. Baranyai Z, Biri-Kovács B, Krátký M, Szeder B, Debreczeni ML, Budai J, Kovács B, Horváth L, Pári E, Németh Z, Cervenak L, Zsila F, Méhes E, Kiss É, Vinšová J, Bősze S. ; J Med Chem. 2021, 25;64(6), 2982-3005. https://doi.org/10.1021/acs.jmedchem.0c01399 
11. Kósa N, Zolcsák Á, Voszka I, Csík G, Horváti K, Horváth L, Bősze S, Herenyi L.; Int J Mol Sci. 2021, 22(5), 2457. https://doi.org/10.3390/ijms22052457

12. Adina Borbély, Lilla Pethő, Ildikó Szabó, Mohammed Al-Majidi, Arnold Steckel, Tibor Nagy, Sándor Kéki, Gergő Kalló, Éva Csősz, Gábor Mező, Gitta Schlosser: Structural Characterization of Daunomycin-Peptide Conjugates by Various Tandem Mass Spectrometric Techniques. Int. J. Mol. Sci. 2021, 22, 1648 . https://doi.org/10.3390/ijms22041648

13. Murányi, J.; Varga, A.; Gyulavári, P.; Pénzes, K.; Németh, C.E.; Csala, M.; Pethő, L.; Csámpai, A.; Halmos, G.; Peták, I.; Vályi-Nagy, I. Novel Crizotinib-GnRH Conjugates Revealed the Significance of Lysosomal Trapping in GnRH-Based Drug Delivery Systems. Int. J. Mol. Sci. 2019, 20, 5590. https://doi.org/10.3390/ijms20225590

14. Biri-Kovács, B.; Adorján, A.; Szabó, I.; Szeder, B.; Bősze, Sz.; Mező, G. Structure-Activity Relationship of HER2 Receptor Targeting Peptide and Its Derivatives in Targeted Tumor Therapy. Biomolecules 2020, 10(2), 183. https://doi.org/10.3390/biom10020183

15. Lv, Q.; Meng, Z.; Yu, Y.; Jiang, F.; Guan, D.; Liang, C.; Zhou, J.; Lu, A.; Zhang, G. Molecular Mechanisms and Translational Therapies for Human Epidermal Receptor 2 Positive Breast Cancer. Int. J. Mol. Sci. 2016, 17, 2095, https://doi.org/10.3390/ijms17122095

16. Fehér, B., Lyngsø, J., Bartók, B., Mihály, J., Varga, Z., Mészáros, R., Pedersen, J. S., Bóta, A., Varga, I. Effect of pH on the conformation of bovine serume albumin - gold bioconjugates. Journal of Molecular Liquids 2020, 309, 11306. https://doi.org/10.1016/j.molliq.2020.113065

17. Bali, K., Bak, M., Szarka, K., Juhász, G., Sáfrán, G., Pécz, B., Mihály, J., Mészáros, R. Controlling the morphology of poly(ethyleneimine)/gold nanoassemblies through the variation of $\mathrm{pH}$ and electrolyte additives. Journal of Molecular Liquids 2021, 322, 114559. https://doi.org/10.1016/j.molliq.2020.114559
18. Banoczi, Z.; Tantos, A.; Farkas, A.; Majer, Z.; Dokus, L.E.; Tompa, P.; Hudecz, F. New m-calpain substrate-based azapeptide inhibitors. J. Pept. Sci. 2013, 19, 370-376. https://doi.org/10.1002/psc.2511

19. Zhang, Y.; Herling, M.; Chenoweth, M.D. General Solution for Stabilizing Triple Helical Collagen J. Am. Chem. Soc. 2016, 138, 9751-9754. https://doi.org/10.1021/jacs.6b03823

20. Bősze, Sz.; Zsila, F.; Biri-Kovács B, Szeder, B.; Majer, Zs.; Hudecz, F.; Uray, K. Tailoring Uptake Efficacy of HSV-1 gD Derived Carrier Peptides. Biomolecules 2020, 10(5), 721. https://doi.org/10.3390/biom10050721

21. Szigyarto, I.Cs.; Mihály, J.; Wacha, A.; Bogdán, D.; Juhász, T.; Kohut, G.; Schlosser, G.; Zsila, F; Urlacher, V.; Varga, Z.; Fülöp, F.; Bóta, A.; Mándity, I.; Beke-Somfai, T. Membrane active Janus-oligomers of $\beta 3$-peptides. Chem. Sci. 2020, 11, 6868-6881. https://doi.org/10.1039/D0SC01344G

22. Ecsédi P., Gógl G., Hóf H., Kiss B., Harmat V., Nyitray L. Structure determination of the transactivation domain of p53 in complex with S100A4 using annexin A2 as a crystallization chaperone Structure 2020, 28, 943-953.e4 https://doi.org/10.1016/j.str.2020.05.001

23. Bösze, Sz.; Zsila, F.; Biri-Kovács B, Szeder, B.; Majer, Zs.; Hudecz, F.; Uray, K. Tailoring Uptake Efficacy of HSV-1 gD Derived Carrier Peptides. Biomolecules 2020, 10(5), 721. https://doi.org/10.3390/biom10050721

24. Lu, S.; Jang, H.; Muratcioglu, S.; Gursoy, A.; Keskin, O.; Nussinov, R.; Zhang, J. Ras Conformational Ensembles, Allostery, and Signaling, Chem. Rev. 2016, 116(11), 6607-65. https://doi.org/10.1021/acs.chemrev.5b00542

25. Zhao, Q.; Fujimiya, R.; Kubo, S.; Marshall C. B.; Ikura, M.; Shimada, I.; Nishida, N. Real-Time In-Cell NMR Reveals the Intracellular Modulation of GTP-Bound Levels of RAS. Cell. Rep. 2020;32(8):108074. https://doi.org/10.1016/j.celrep.2020.108074 


\section{ELTE's program of excellence to increase the capacity in synthetic chemistry and biochemistry: Synthesis+}

The Latin word synthesis - assembling and uniting - is also a scientific terminus technicus referring to the production of more complex molecules or materials. Today, most of the 2,000 active compounds available in pharmacies in forms of various medications are synthetic. However, synthetic chemistry and biochemistry are much more than this; most of our clothing, equipment, vehicles, and other items of use are a cleverly assembled systems of synthetic materials. Therefore, the development and expansion of synthetic, analytical and technological knowledge and capacity is a top priority.

The direct objective of the Synthesis + excellence program is to develop and expand the synthetic capacity of ELTE TTK. The indirect goal of the program is to strengthen, coordinate and enhance the synergies between colleagues, working groups and communities related to synthetic works, so that we can be more effective in research and development, and bring focus to selected areas of innovation. Thus, in the forthcoming years, we plan to

- strengthen, link and network different synthetic and associated disciplines,

- introduce the practice of cooperation and competition,

- catalyze specialty synergy,

- promote collaboration between successful researchers and

- provide financial support for the best.

Based on their size and chemical constitution, we plan to begin with the development of four research areas : 1) organic small molecules, 2) oligo- and polypeptides, 3) proteins, and 4) biosimilars and bioassays. These four themes cover the major areas of domestic drug, fine chemicals and agrochemistry, requiring broad-profile cooperation.

1) In the context of the structure-activity relationship (QSAR), we start or continue to develop small organic molecules. We will work on the synthesis and cost-effective scale-up of naturally occurring bioactivity compounds, potential active agents, targeting their market exploitation. Furthermore, we will work on the design and synthesis of skeletal and fragment-based compounds.

2) We will develop amino acid, peptide, and protein fragment-based active substances as guiding (targeting?) peptides and bifunctional linker libraries for personalized medicine, producing a large number of specific and selective peptide conjugates. We will produce and test radiotherapy and diagnostic (PET, MRI) products in cooperation with external partner institutions (e.g. National Oncology Institute and SE). We will develop a new flow-chemistry method for the efficient and environmentally friendly synthesis of polypeptides.

3) Bacterial expression systems will be developed and optimized for fermentation to aid the production of isotopically labeled proteins. We will produce key proteins according to research and market needs, develop and analyze lead molecules related to certain diseases (e.g. type 2 diabetes, neurodegenerative diseases, oncogenic and muscle proteins, steroid-resistant kidney disease,..).

4) The development of biosimilar molecules (/materials?) and bioassays is a key economic challenge. Protein-based in vitro drug tests and in vivo disease models will be developed to test potential active ingredients, lead compounds etc. of section 3 .

Many of the scientists, chemists and biologists involved in these projects are internationally well-known researchers. Excellent synthetic chemists and biochemists, spectroscopists, molecular modelers, applied quantum chemists, material scientists, biocompatible and bioactive molecule specialists as well as researchers of outstanding scientific indicators form the core team of this excellence program. They all have prestigious international connections and scientific networks and are members of important international panels, boards and committees.

In summary, we will catalyze, strengthen and make more efficient our current synthetic capacities exactly where our scientific community needs it the most. This excellence program will be developed, partly based on previous pilot studies (e.g. MedInProt / ELTE, HunProtExc / NKFIH, Research Groups / MTA-ELTE, etc.), alongside the development of established and proven structures. We also want to provide an opportunity

- to formulate and start new research topics,

- to stimulate researcher mobility,

- to enhance effective and efficient cooperation,

- to create a XXI. century synthetic research environment,

- to build bridges toward the industry.

Relying on the experience-pool of previous integration and cooperation projects, the aim of the Synthesis + excellence program is the introduce synergy between researchers of synthetic chemistry and biology and thereby strengthen their integration so that we can be even more efficient, competitive and successful. 